Technical Task Request HLW/DWPF/TTR-00-0016, Rev. 1:

\title{
Confirmation Run of the DWPF SME Cycle and Results of the Glass Analysis Using the Sludge-Only Flowsheet with Tank 40 Radioactive Sludge and Frit 200 in the Shielded Cells Facility (U)
}

\author{
T.L. Fellinger, J.M. Pareizs, N.E. Bibler, A.D. Cozzi, and C.L. Crawford
}

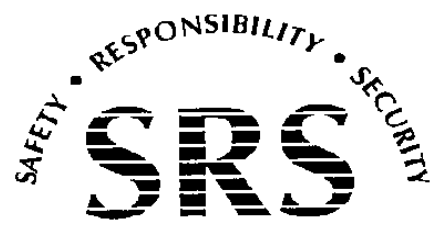


This document was prepared in conjunction with work accomplished under Contract No. DE-AC09-96SR18500 with the U. S. Department of Energy.

\section{DISCLAIMER}

This report was prepared as an account of work sponsored by an agency of the United States Government. Neither the United States Government nor any agency thereof, nor any of their employees, makes any warranty, express or implied, or assumes any legal liability or responsibility for the accuracy, completeness, or usefulness of any information, apparatus, product or process disclosed, or represents that its use would not infringe privately owned rights. Reference herein to any specific commercial product, process or service by trade name, trademark, manufacturer, or otherwise does not necessarily constitute or imply its endorsement, recommendation, or favoring by the United States Government or any agency thereof. The views and opinions of authors expressed herein do not necessarily state or reflect those of the United States Government or any agency thereof.

This report has been reproduced directly from the best available copy.

Available for sale to the public, in paper, from: U.S. Department of Commerce, National Technical Information Service, 5285 Port Royal Road, Springfield, VA 22161, phone: (800) 553-6847, fax: (703) 605-6900

email: orders@ntis.fedworld.gov

online ordering: http://www.ntis.gov/help/index.asp

Available electronically at http://www.osti.gov/bridge

Available for a processing fee to U.S. Department of Energy and its contractors, in paper, from: U.S. Department of Energy, Office of Scientific and Technical Information, P.O. Box 62, Oak Ridge, TN 37831-0062,

phone: (865)576-8401,

fax: (865)576-5728

email: $\underline{\text { reports@ adonis.osti.gov }}$ 
WSRC-TR-2002-00096

Keywords: Tank 40, Frit 200, DWPF, SME, Sludge Batch 2, Macrobatch 3

Retention: Permanent

Task Technical Request HLW/DWPF/TTR-00-0016, Rev. 1:

Confirmation Run of the DWPF SME Cycle and Results of the Glass Analysis Using the Sludge-Only Flowsheet with Tank 40 Radioactive Sludge and Frit 200 in the Shielded Cells Facility (U)

T.L. Fellinger, J.M. Pareizs, N.E. Bibler, A.D. Cozzi, and C.L. Crawford

Publication Date: June 26, 2002

Westinghouse Savannah River Company

Savannah River Site

Aiken, SC 29808

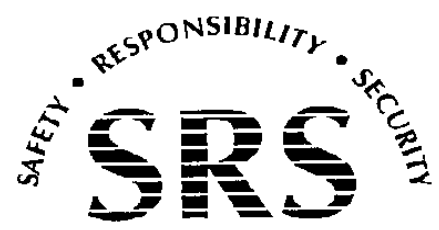

PREPARED FOR THE U.S. DEPARTMENT OF ENERGY UNDER CONTRACT NO. DE-AC09-96SR18500 
WSRC-TR-2002-00096

Revision 0
Westinghouse Savannah River Company Savannah River Technology Center

APPROVALS

En thetzachects

E.W. Holtzscheiter

Section Manager, Level 3

Immobilization Technology Section

Savannah River Technology Center
$6-27-02$

Date

6.27-02

Date

$\frac{6 / 26 / 02}{\text { Date }}$

$\frac{6 / 36 / 02}{\text { Date }}$

$\frac{6 k 7102}{\text { Date }}$

$6 / 26 / 02$

$\frac{6 / 26 / 02}{\text { Date }}$

$6 / 26 / 02$

$6 / 26 / 02$

Date

Cel26/92 


\section{TABLE OF CONTENTS}

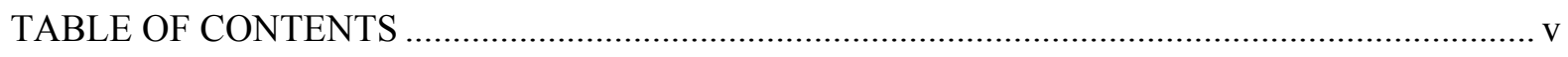

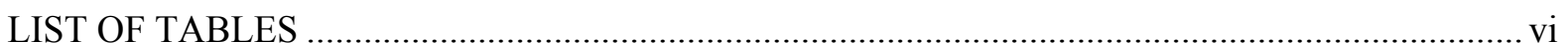

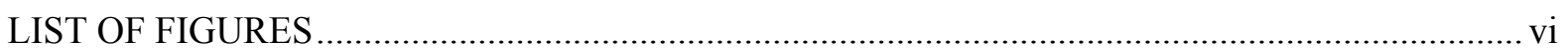

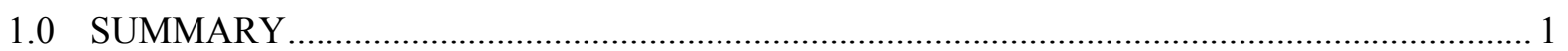

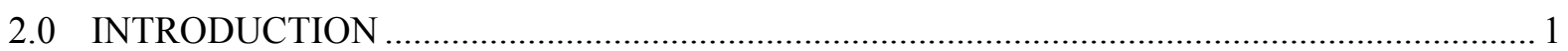

3.0 DESCRIPTION OF THE SYSTEM AND CALCULATIONS USED TO PERFORM

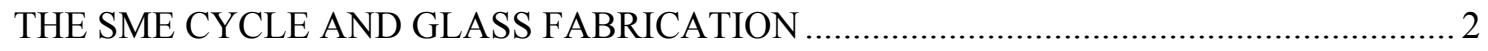

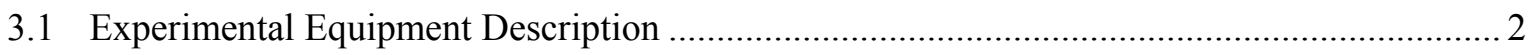

3.2 Calculations for the Blending of the Frit 200 and SRAT Product Compositions ................... 4

4.0 DESCRIPTION OF THE SME CYCLE, GLASS FABRICATION, GLASS ANALYSIS, AND SME REDOX ADJUSTMENT CYCLE .............................................. 4

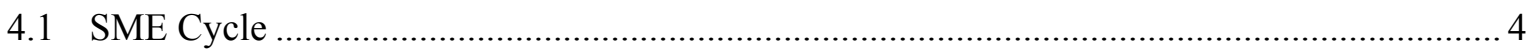

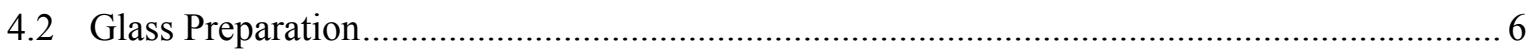

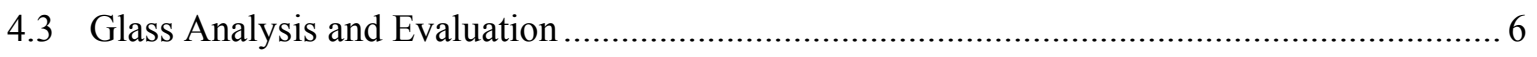

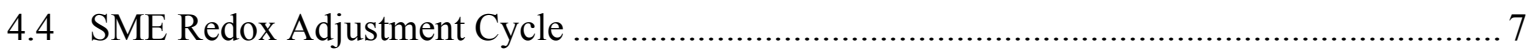

5.0 RESULTS AND DISCUSSION OF THE SME CYCLE, GLASS ANALYSIS AND EVALUATION, AND SME REDOX ADJUSTMENT CYCLE ............................................ 8

5.1 Weight Percent Solids, Weight Percent Calcined Solids, and Density Measurements

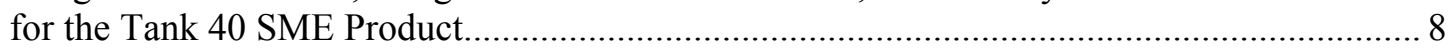

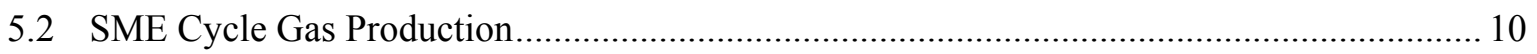

5.3 Chemical Composition of Vitrified SME Product ............................................................... 12

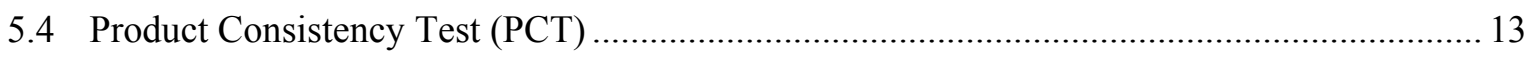

5.5 Examination of the Tank 40/Frit 200 Glass by Scanning Electron Microscopy .................... 16

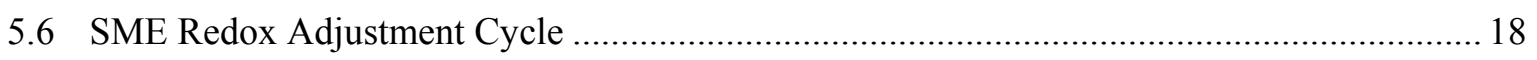

6.0 ACCEPTABILITY OF THE GLASS USING PRODUCT COMPOSITION CONTROL

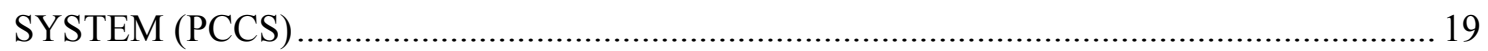

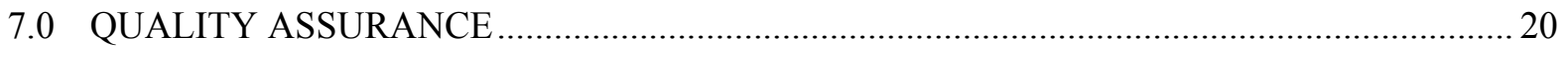

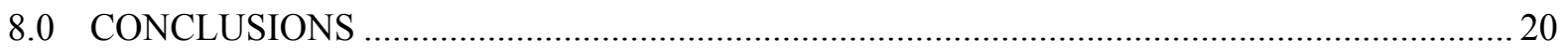

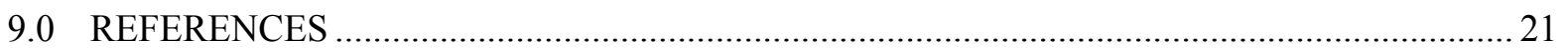

APPENDIX A - INPUTS AND ASSUMPTIONS USED FOR CONVERTING FROM SRTC

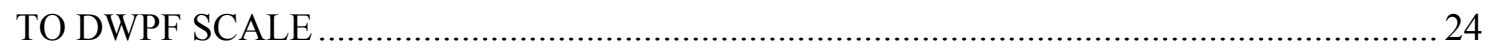

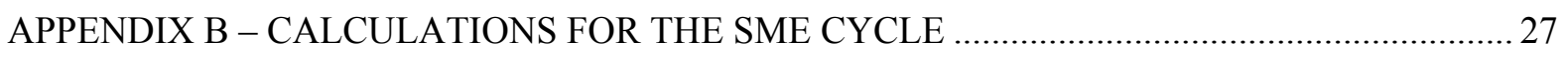

APPENDIX C - CALCULATIONS FOR THE SME REDOX CYCLE ...........................................2 28 
WSRC-TR-2002-00096

\section{LIST OF TABLES}

Table 1 - Information Used to Complete the Blending Calculations for the SRTC SME Cycle ........... 4

Table 2 - Processing Parameters During the SRTC SME Cycle.......................................................... 6

Table 3 - Processing Parameters During the SME Redox Adjustment Cycle …................................. 8

Table 4 - Weight Percent Solids, Weight Percent Calcined Solids, Density Measurements, and Vitrification Factor for the Tank 40 SME Product

Table 5 - Maximum Hydrogen, Carbon Dioxide, and Nitrous Oxide Generation During the SME Cycle.

Table 6 - Required Elements (excluding oxygen) for Checking the SME Acceptability for the Tank 40 /Frit 200 SRTC Vitrified SME Product

Table 7 - Average Measured and Calculated Composition (Major Oxide Wt\%) of the Vitrified SME Product.

Table 8 - Normalized PCT Results for Major Nonradioactive Element in Tank 40 Frit 200 Glass and for the Environmental Assessment Glass

Table 9 - Normalized PCT Results for Major Nonradioactive Elements and Several Radionuclides in Tank 40 Frit 200 Glass

Table 10 - Maximum Observed Gas Concentrations and Generation Rates During the SRTC SME Redox Cycle

\section{LIST OF FIGURES}

Figure 1 - Picture of the SRAT/SME Vessel in the Mockup Cells of the Shielded Cells Facility

Figure 2 - Picture of the Top View of the Connections/Ports for the SRAT/SME Vessel Prior to Entry into the Shielded Cells ......

Figure 3 - SRTC Scale Hydrogen, Carbon Dioxide, and Nitrous Oxide Concentrations and $\mathrm{pH}$ in the Offgas During the SME Cycle

Figure 4 - SEM Micrographs of the Vitrified SME Product Sample at 50x. 16

Figure 5 - EDS Spectrum of Vitrified SME Product

Figure 6 - SEM Micrograph of the Representative Particle Identified in Figure 4 at 500x

Figure 7 - SRTC Scale Hydrogen, Carbon Dioxide, and Nitrous Oxide Concentrations and pH During the SME Redox Adjustment Cycle. 


\subsection{SUMMARY}

Several basic data reports ${ }^{1,2,3}$ have been issued concerning the recent demonstration of the Defense Waste Processing Facility (DWPF) Sludge Receipt and Adjustment Tank (SRAT) Cycle and Slurry Mix Evaporator (SME) Cycle conducted at the Savannah River Technology Center (SRTC) in support of Sludge Batch 2 (Macrobatch 3). This report describes in detail the SME cycle; glass fabrication, analysis, and acceptability; and the SME Redox Adjustment cycle.

For the SME cycle, water was added to the SRAT product ${ }^{*}$ and then evaporated to simulate the addition and removal of decon water from the canister decontamination process. Frit 200 and dilute formic acid were then added to the SME vessel. Finally, the SME contents were concentrated to 45 $\mathrm{wt} \%$ solids. During the SME cycle, no foaming was observed, and hydrogen gas generation was well below DWPF limits. It should be noted that SRTC followed DWPF's current antifoam addition strategy as recommended by Koopman ${ }^{4}$ (addition of IIT747 antifoam prior to boiling, and every eight hours thereafter).

A small amount of SME product was then vitrified. The resulting glass was analyzed for chemical composition and evaluated using the Product Consistency Test (to measure the glass durability). Based on the chemical composition, the SME product was predicted to produce acceptable glass per the Product Composition Control System (PCCS) ${ }^{\dagger}$. Also, as determined by the PCT, the glass was significantly more durable than the Environmental Assessment (EA) glass.

In the event that the redox of the SME would need to be adjusted, SRTC added concentrated formic acid to the remaining SME product to evaluate gas generation during the SME Redox Adjustment cycle. While there was some evidence of denitration and more carbon dioxide and hydrogen were produced than during the SME cycle (as expected), no foaming was observed, and hydrogen generation was still well below DWPF limits.

This demonstration was requested by the DWPF through a Technical Task Request (HLW/DWPF/TTR-00-0016, Rev. 1) $)^{5}$.

\subsection{INTRODUCTION}

The DWPF is currently processing and immobilizing radioactive sludge slurry into a durable borosilicate glass. After successfully processing Sludge Batch 1B (Macrobatch 2) for approximately 3 years, the DWPF was in need of a new batch of radioactive sludge slurry to continue canistered waste form production. The next batch of radioactive sludge slurry to be processed by the DWPF is called Sludge Batch 2 (Macrobatch 3). Sludge Batch 2 is a mixture of the sludge slurry that was transferred from Tank 8 and the sludge slurry that already existed in Tank 40 . Tank 40 is one of the two tanks (the other feed tank is Tank 51) that directly feeds the DWPF.

\footnotetext{
* The SRAT product produced in the Shielded Cells is described in Reference 11, "Confirmation Run of the DWPF SRAT Cycle Using the Sludge-Only Flowsheet with Tank 40 Radioactive Sludge and Frit 200 in the Shielded Cells Facility (U)."

$\dagger$ The glass was not acceptable for chromium (see Reference 27). However, the chromium is attributed to contamination from the steel grinder used to prepare the glass for analysis.
} 
Prior to processing a new sludge batch in DWPF, SRTC-Immobilization Technology Section (ITS) must analyze and confirm that each sludge batch produces an acceptable glass ${ }^{6}$. Part of this effort is to perform a glass variability study using nonradioactive simulants and frit (glass forming chemicals) to verify the applicability of the composition/PCT correlation ${ }^{7}$. Another portion of this sludge qualification effort is to perform process testing using nonradioactive sludge slurry simulants prior to processing the actual radioactive material in the Shielded Cells ${ }^{4}$. Finally, an actual sample of the radioactive material is processed in the Shielded Cells and glass is produced to demonstrate the acceptability of the sludge batch ${ }^{8,9,10}$.

To perform the Shielded Cells demonstration, twelve dip samples ( $220 \mathrm{~mL} / \mathrm{each}$ dip sample) were obtained from Tank 40, prior to sludge washing, and sent to the SRTC Shielded Cells Facility. The samples were combined and an initial composition of the radioactive sludge slurry was obtained. Since the sludge was unwashed and sodium concentration of the sludge slurry did not meet the DWPF acceptance criteria, a demonstration of the Tank Farm's Extended Sludge Processing (ESP) was performed by the Waste Processing Technology Section (WPTS). The sludge slurry was washed to a target endpoint of $0.55 \mathrm{M} \mathrm{Na}( \pm 0.05 \mathrm{M} \mathrm{Na})$ in the supernate to meet the acceptance criteria of the DWPF. Upon receipt of the washed sludge slurry from WPTS, a demonstration of the DWPF "Sludge-Only" flowsheet was performed using approximately one liter of sludge slurry. The DWPF "Sludge-Only" flowsheet calls for processing radioactive sludge slurry using nitric acid, concentrated formic acid, and Frit 200 through the Chemical Processing Cell (CPC) of DWPF.

Information concerning processing, offgas data, and analyses of the final washed sludge slurry composition and final SRAT product can be found in a previous report ${ }^{11}$. Information concerning the SME cycle, vitrification, non-radioactive chemical analyses of the SME product, Product Consistency Test results, and SME Redox Adjustment Cycle are presented in this report. Radionuclide analyses of the SME product will be reported in a later report.

\subsection{DESCRIPTION OF THE SYSTEM AND CALCULATIONS USED TO PERFORM THE SME CYCLE AND GLASS FABRICATION}

The sections below provide a description of the system used in the Shielded Cells to perform the Tank 40 demonstration and the data used to calculate the amounts of glass frit needed to complete the SME cycle.

\subsection{Experimental Equipment Description}

The SRAT/SME vessel used in this confirmation run is a glass cylinder approximately 13 inches in height and 6 inches in diameter. The SRAT/SME vessel has a capacity of approximately 2 liters, and the top of the SRAT/SME vessel has a series of ports and openings. These ports and openings are for the installation of equipment (i.e. $\mathrm{pH}$ probe, thermocouple, agitator, etc.) and process lines (acid addition, air purge, etc.). The condenser, mercury/condensate trap, and cold trap connected to the SRAT/SME vessel are also made out of glass.

To supply heat to the SRAT/SME vessel, a heating mantle is used. Also, a laboratory chiller unit is used to supply the chilled water for the condenser. Figure 1 is a picture taken in the Mockup Cells of the system prior to installation in the Shielded Cells.

Figure 2 is a picture of the top portion of the vessel showing the ports/openings for the SRAT/SME vessel. 
Figure 1 - Picture of the SRAT/SME Vessel in the Mockup Cells of the Shielded Cells Facility

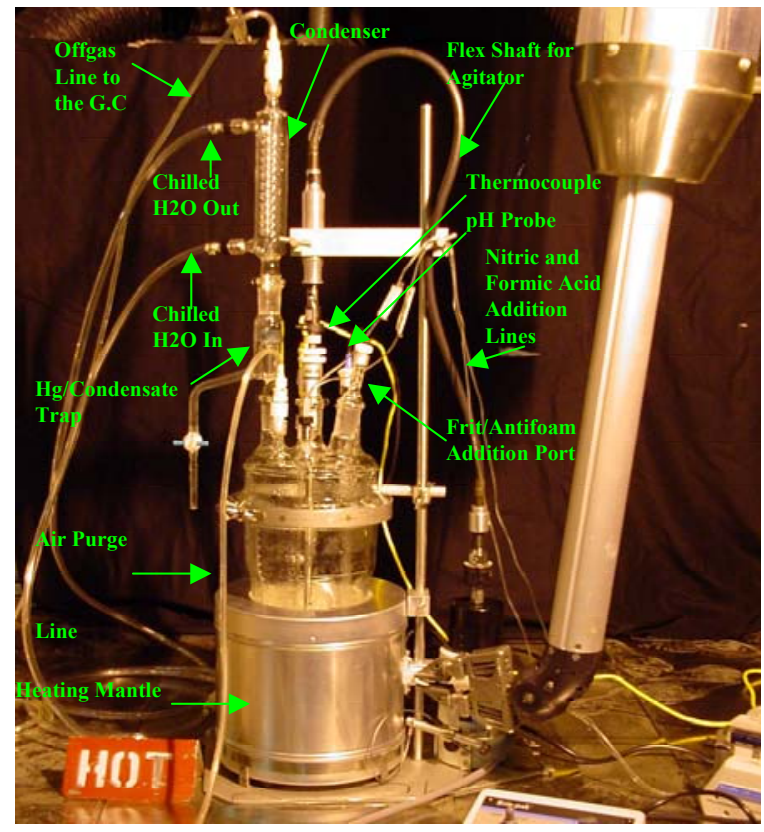

Figure 2 - Picture of the Top View of the Connections/Ports for the SRAT/SME Vessel Prior to Entry into the Shielded Cells

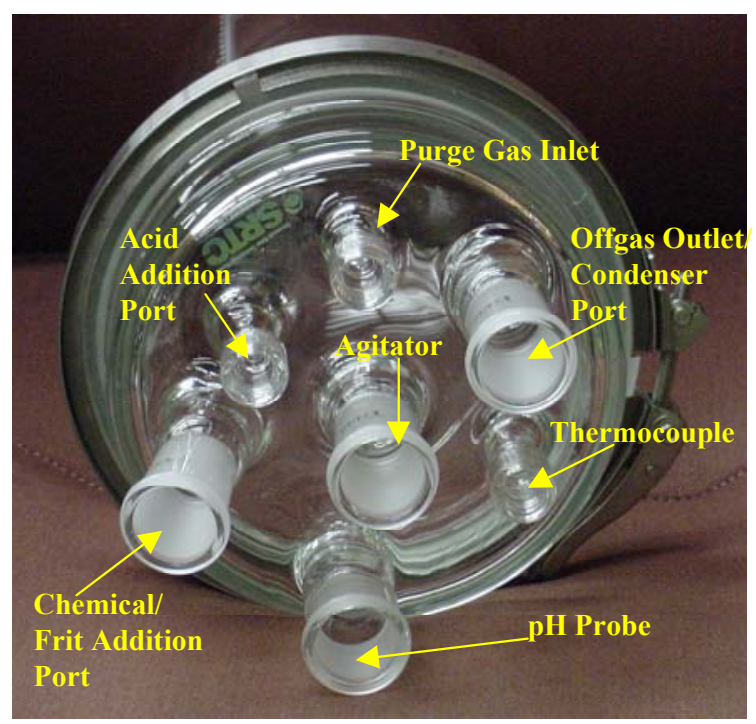

The SRAT/SME is purged using air with $0.5 \%$ (nominal) helium. By measuring the helium in the vessel purge, gas generation rates can be calculated. The purge gas composition is measured using a Varian CP-2002 Micro-GC gas chromatograph (GC). Column A contains a Molsieve 5A column with argon carrier gas. It separates helium, hydrogen, oxygen, and nitrogen. Column B contains a PoraPlot Q column with nitrogen carrier gas. It separates carbon dioxide and nitrous oxide. The GC is located in a radiohood behind the Shielded Cells. 
A CM FURNACES Model 1708 BL bottom loading box furnace was used to vitrify the SME product. The furnace was equipped with a programmable controller that enabled the control of furnace heatup.

\subsection{Calculations for the Blending of the Frit 200 and SRAT Product Compositions}

To determine the amount of Frit 200 to be added to the SRAT product for the SME cycle, SRTC provided Waste Disposition (WD) Engineering with the SRAT product volume and composition ${ }^{12}$. WD Engineering used this information to complete the blending calculations. The results of the calculations were documented in a memo and transmitted to SRTC prior to the start of the SME cycle $^{13}$. Table 1 presents the SRTC SRAT product composition ${ }^{11}$, the Frit 200 composition (from WD Engineering), and resulting calculated blend composition for the SRTC SME cycle.

Table 1 - Information Used to Complete the Blending Calculations for the SRTC SME Cycle

\begin{tabular}{|c|c|c|c|}
\hline & SRTC SRAT Product & Frit 200 & $\begin{array}{c}\text { Calculated SRAT } \\
\text { Product/ Frit 200 } \\
\text { Blend }\end{array}$ \\
\hline Wt\% Total Solids & 20.2 & 45.0 & 51.00 \\
\hline Calcined Wt\% Solids & 15.7 & 45.0 & 46.70 \\
\hline Specific Gravity & 1.15 & 1.30 & 1.463 \\
\hline Elements & $\begin{array}{c}\text { Ave. Elemental Wt. \% } \\
\text { (dried slurry basis) }\end{array}$ & $\begin{array}{c}\text { Ave. Elemental Wt. \% } \\
\text { (vitrified basis) }\end{array}$ & $\begin{array}{c}\text { Elemental Wt. \% } \\
\text { (vitrified basis) }\end{array}$ \\
\hline $\mathrm{Al}$ & 5.56 & 0.36 & 2.262 \\
\hline $\mathrm{B}$ & 0.03 & 3.59 & 2.554 \\
\hline $\mathrm{Ca}$ & 2.19 & 0.18 & 0.915 \\
\hline $\mathrm{Cr}$ & 0.15 & -- & 0.054 \\
\hline $\mathrm{Cu}$ & 0.04 & -- & 0.015 \\
\hline $\mathrm{Fe}$ & 22.3 & 0.04 & 8.076 \\
\hline $\mathrm{K}$ & 0.04 & 0.12 & 0.097 \\
\hline $\mathrm{Li}$ & 0.07 & 2.23 & 1.605 \\
\hline $\mathrm{Mg}$ & 1.77 & 1.17 & 1.465 \\
\hline $\mathrm{Mn}$ & 2.97 & -- & 1.072 \\
\hline $\mathrm{Na}$ & 7.88 & 8.07 & 8.567 \\
\hline $\mathrm{Ni}$ & 1.13 & -- & 0.408 \\
\hline $\mathrm{Si}$ & 0.99 & 32.32 & 23.282 \\
\hline $\mathrm{Ti}$ & 0.02 & 0.03 & 0.029 \\
\hline $\mathrm{U}$ & 6.85 & -- & 2.472 \\
\hline $\mathrm{Zr}$ & 0.02 & -- & 0.006 \\
\hline $\mathrm{Volume}$ & $722 \mathrm{~mL}$ & $\mathrm{~N} / \mathrm{A}$ & $\mathrm{N} / \mathrm{A}$ \\
\hline $\mathrm{Weight}$ & $\mathrm{N} / \mathrm{A}$ & $329.76 \mathrm{~g}$ & \\
\hline & & & \\
\hline & & & \\
\hline & & & \\
\hline & & & \\
\hline
\end{tabular}

\subsection{DESCRIPTION OF THE SME CYCLE, GLASS FABRICATION, GLASS ANALYSIS, AND SME REDOX ADJUSTMENT CYCLE}

\subsection{SME Cycle}

Initiation - Heating and Agitation

Initiation of the SME cycle began at 0715 on 17 October 2001 when the agitator to the SME vessel was turned on. Heatup of the vessel began at 0730 when power was supplied to the heating mantle. 
Antifoam was added at 0835 when the vessel temperature reached $50^{\circ} \mathrm{C}$. Additional antifoam was added every eight hours thereafter.

Decon Water Addition and Removal

At 1044, with the SME contents boiling, water was added to the vessel to simulate the addition of water from the decontamination of five canisters. Water addition took approximately 50 minutes. This water was then boiled off over the next nineteen hours.

Frit/Formic Acid Addition

On 18 October 2001 at 0720 , the first of two frit additions began. First, dry frit was poured into the vessel. Second, dilute formic acid was pumped into the vessel. Third, the vessel contents were boiled to reduce the volume to its original level. Beginning at 1430, the second frit/formic acid addition/concentration was begun.

\section{Final Concentration}

Upon reaching approximately 45 weight percent total solids, during the SME cycle, the condensate collection rate decreased from approximately $0.24 \mathrm{~mL} / \mathrm{min}$ to approximately $0.12 \mathrm{~mL} / \mathrm{min}$. The heat to the vessel was increased, but the condensate rate remained unchanged. This indicated that the target weight percent total solids of $51 \%$ was not achievable due to the inability to transfer more heat to the vessel. At 2300 on 18 October 2001, with WD Engineering concurrence, the SME cycle was concluded when heat to the vessel was turned off.

\section{Antifoam Additions}

The antifoam strategy (as recommended by Koopman ${ }^{4}$ ) of adding 100 ppm of IIT747 antifoam before boiling and refreshing with additions of $100 \mathrm{ppm}$ antifoam every eight hours thereafter was followed. It should be noted that for the Shielded Cells SME cycle the first antifoam addition occurred when the vessel temperature reached $50^{\circ} \mathrm{C}$ rather than just before boiling. No unscheduled antifoam additions were required during the SME cycle.

Following the SME cycle, the SME product was sampled for weight percent total solids and density measurements. A sample was also removed for vitrification (see following section). The remaining SME product was left in the vessel for the SME Redox Cycle (see Section 4.4). Table 2 lists some of the key processing parameters during the SME Cycle. Appendix B shows the calculations used for the SME cycle. 
WSRC-TR-2002-00096

Westinghouse Savannah River Company

Revision 0

Savannah River Technology Center

Table 2 - Processing Parameters During the SRTC SME Cycle

\begin{tabular}{|l|c|l|}
\hline Parameter & Value & Comment \\
\hline Purge Rate & $20.5 \mathrm{cc} / \mathrm{min}$ & $\begin{array}{l}\text { SRTC purge is } 1 / 3 \text { of DWPF scale for better } \\
\text { gas measurement sensitivity. }\end{array}$ \\
\hline SRTC SME Volume & $722 \mathrm{~mL}$ & $\begin{array}{l}\text { For comparison purposes, it is assumed that } \\
\text { the DWPF SME volume is } 6,000 \text { gal. }\end{array}$ \\
\hline $\begin{array}{l}\text { Decon Water Volume and Addition } \\
\text { Rate }\end{array}$ & $602 \mathrm{~mL}$ at $12 \mathrm{~mL} / \mathrm{min}$ & $\begin{array}{l}\text { This corresponds to the decon water for } 5 \\
\text { canisters. }(1,000 \text { gal/can, SME volume of } \\
6,000 \text { gal). }\end{array}$ \\
\hline Frit Addition & $329.76 \mathrm{~g}$ & Calculated by WD Engineering. \\
\hline Dilute Formic Acid Added & $335.3 \mathrm{~g}$ at $1.5 \mathrm{wt} \%$ & $\begin{array}{l}\text { Rather than mixing frit and formic acid as } \\
\text { DWPF, SRTC added the frit and acid } \\
\text { separately in two equal batches (frit, acid, } \\
\text { then frit, acid). }\end{array}$ \\
\hline IIT747 Antifoam Added & $\begin{array}{l}\text { 1.66 } \mathrm{mL} \text { of a } 5 \mathrm{wt} \% \\
\text { solution per addition }\end{array}$ & $\begin{array}{l}\text { This amount of antifoam solution is intended } \\
\text { to give an antifoam concentration in the } \\
\text { vessel of } 100 \text { ppm. }\end{array}$ \\
\hline
\end{tabular}

Note that the values above are those actually used during the SME cycle. They may be slightly different than the calculated values given in Appendices $A$ and $B$.

\subsection{Glass Preparation}

The glass was prepared remotely by drying and melting the SME product slurry in a $100-\mathrm{mL}$ platinum crucible in a programmable electric furnace in Cell 1 of the Shielded Cells. The crucible was partially filled with 102.5 grams of the SME product slurry (45.3 wt. \% solids). The crucible was placed in a drying oven in Cell 1 at $40^{\circ} \mathrm{C}$, heated to $106^{\circ} \mathrm{C}$, and held for 6.5 hours to dry. After drying, a thin layer of white material was noted on the surface. This material was probably dried salts that were soluble in the slurry. The crucible containing the SME product was then set in a kyanite catch crucible and placed into the furnace. The furnace was programmed to ramp up to $1150^{\circ} \mathrm{C}$ in four hours. When the furnace reached $1150^{\circ} \mathrm{C}$, the temperature was maintained for 4 hours. The heating steps (drying, ramped heating, and high-temperature hold) are to ensure dryness, decomposition of the nitrates and any residual nitrites, and to provide the opportunity to produce a homogeneous melt. The crucible was then removed from the furnace at temperature. The glass was quenched by setting the crucible in a shallow pan of water (i.e., water only had contact with the outside of the crucible) and then allowed to cool to ambient temperature in the cell. The cooled glass was then removed from the crucible and stored in a labeled jar.

\subsection{Glass Analysis and Evaluation}

The measured elemental composition of the glass was obtained by dissolving samples of the ground glass and analyzing the resulting solutions using Inductively Coupled Plasma - Emission Spectroscopy (ICP-ES). Dissolution of the glass samples was performed remotely in the Shielded Cells of SRTC. A portion of the glass sample was dissolved in quadruplicate by two separate dissolution methods, mixed acid dissolution and sodium peroxide fusion, according to approved procedures ${ }^{9}$. The acid dissolution method uses boric acid to complex the fluorine used to help dissolve the glass. Thus, the boron content of the glass cannot be obtained by this method. The sodium peroxide fusion uses sodium peroxide to convert the glass to hydroxide salts that are then dissolved in acid. Thus, the sodium content of the glass cannot be obtained by this method. All 
fusions were performed in zirconium crucibles; thus, the zirconium content of the glass could not be obtained by this method. The silicon in the glass is best determined by the peroxide fusion method because of incomplete dissolutions by the mixed acids. Calcium, copper, and iron are present as impurities in the zirconium crucibles, so these elements were determined by the mixed acid dissolution. Uranium was determined by Inductively Coupled Plasma - Mass Spectroscopy (ICPMS). This technique is not applied to the solutions from the peroxide fusion method because the high concentration of the sodium affects the performance of the instrument. Thus uranium was determined by analyzing solutions from the mixed acid dissolution.

The samples for the dissolutions were obtained from the glass that was ground in a stainless steel grinder and then sieved for the PCT (see below). The glass used for dissolutions passed through a 200 -mesh $(<74 \mu \mathrm{m})$ sieve. Since the glass was ground in a stainless steel grinder, some stainless steel contamination was present in the glass samples used for dissolutions ${ }^{\ddagger}$. The additional iron from the steel does not significantly affect the final glass composition or property predictions because of the large amount of iron already in the glass. However, the chrome addition from the stainless steel, albeit small in an absolute sense, can affect the Cr concentration in the final glass. A standard glass with a composition similar to the DWPF glass, Analytical Reference Glass-1 (ARG-1) ${ }^{14}$, was also dissolved and analyzed concurrently with the Tank 40/Frit 200 glass. Results for oxides present in amounts greater than one weight percent were within five percent of the published values. This indicates that the dissolutions were complete and the analytical procedures were performed correctly.

A qualitative measure of glass composition and an assessment of homogeneity with respect to crystallization were obtained by examining a glass sample using a Scanning Electron Microscopy (SEM) with X-ray Energy Dispersive Spectroscopy (EDS).

In addition to composition, the glass quality was evaluated using the Product Consistency Test (PCT) Part $\mathrm{A}^{15}$. The PCT, a crushed glass leach test using ASTM Type I water, was performed in quadruplicate in Cell 14 on crushed, ground samples of the glass. The test, which was performed at $90^{\circ} \mathrm{C}$ for seven days, included the Environmental Assessment (EA) ${ }^{16}$ glass, appropriate blanks, and standard ARM-1 glass.

The concentrations of several elements and radionuclides in the leachate were measured using ICPES, Inductively Coupled Plasma - Mass Spectroscopy (ICP-MS), and radioactive counting techniques. The concentrations were used along with the measured chemical composition of the glass to calculate the average normalized releases in terms of grams of glass dissolved per liter of leachate based on specific elements and radionuclides in the glass.

\subsection{SME Redox Adjustment Cycle}

Initiation - Heating and Agitation

The SME Redox Adjustment Cycle began on 12 December 2001 at 0717 when the vessel agitator and heater were turned on. Upon reaching $50^{\circ} \mathrm{C}$ in the vessel (0817), a $100 \mathrm{ppm}$ addition of IIT747 antifoam was made.

\section{$\underline{\text { Formic Acid Addition }}$}

\footnotetext{
* With the concurrence of WD Engineering (personal communication between S. L. Marra (SRTC) and J. E. Occhipinti (WDE)), a stainless steel grinder was used with the knowledge that grinding of the glass could impart stainless contamination to the ground glass. This was done because it relieved scheduling problems in the SRTC shielded cells.
} 
Formic acid addition began at 1008, and was completed at 1155 . The vessel temperature remained approximately $91{ }^{\circ} \mathrm{C}$ during the addition. Due to the uncertainty of foam potential from the acid additon, an antifoam addition was made at 1215 . It should be noted that no foaming was observed.

$\underline{\text { Reflux }}$

At 1450, boiling was observed, and the vessel was allowed to reflux (i.e., no condensate was removed during boiling). At 1850, the process was stopped by turning off the heater and agitator, and discontinuing offgas sampling. Table 3 lists some of the key processing parameters. Appendix C shows the calculations used for the SME Redox Adjustment cycle.

Table 3 - Processing Parameters During the SME Redox Adjustment Cycle

\begin{tabular}{|l|c|l|}
\hline Parameter & Value & Comment \\
\hline Purge Rate & $14.5 \mathrm{cc} / \mathrm{min}$ & $\begin{array}{l}\text { SRTC purge is 1/3 of DWPF scale for better } \\
\text { gas measurement sensitivity. }\end{array}$ \\
\hline SME Product Wt\% Total Solids & 45.3 & $\begin{array}{l}\text { DWPF targets between } 45 \text { and } 51 \mathrm{wt} \% \text { total } \\
\text { solids for SME product. }\end{array}$ \\
\hline Formic Acid Added & $540 \mathrm{~mL}$ & $\begin{array}{l}\text { For comparison purposes, it is assumed that } \\
\text { the DWPF final SME product volume is } \\
6,000 \text { gal. }\end{array}$ \\
\hline Reflux Time & $\begin{array}{l}25.2 \mathrm{~mL} \text { of } 90 \mathrm{wt} \% \\
(22.8 \mathrm{M})\end{array}$ & $\begin{array}{l}\text { This corresponds to 280 gal of formic acid } \\
\text { added to } 6000 \text { gal of SME Product in the } \\
\text { DWPF }\end{array}$ \\
\hline IIT747 Antifoam Added & $\begin{array}{l}\text { DWPF does not reflux the SME after a } \\
\text { formic acid addition. SRTC refluxed the } \\
\text { vessel several hours to measure worst case } \\
\text { hydrogen generation. }\end{array}$ \\
\hline
\end{tabular}

Note that the values above are those actually used during the SME redox adjustment cycle. They may be slightly different than the calculated values given in Appendix $A$ and $C$.

\subsection{RESULTS AND DISCUSSION OF THE SME CYCLE, GLASS ANALYSIS AND EVALUATION, AND SME REDOX ADJUSTMENT CYCLE}

\subsection{Weight Percent Solids, Weight Percent Calcined Solids, and Density Measurements for the Tank 40 SME Product}

Quadruplicate measurements of the total weight percent solids for the sludge slurry were completed remotely in the SRTC Shielded Cells. Mixed portions of a sample of SME product were pipetted into four labeled, pre-weighed $\mathrm{PMP} \circledast$ beakers. After the addition of the mixed SME product, the PMP ${ }^{\circledR}$ beakers were weighed and placed into a drying oven at $115^{\circ} \mathrm{C}$ overnight. The samples were removed from the oven and were allowed to cool for $\sim 5$ minutes before they were weighed. To check the accuracy and precision of the method, three samples of a $15 \mathrm{wt} . \% \mathrm{NaCl}$ standard solution were also weighed and dried (in labeled PMP $®$ beakers) along with the SME product samples. The results of the standard solutions showed good reproducibility and good agreement with the known value of the standard $^{29}$. The averages, standard deviations (Std. Dev.), and the percent relative standard deviations 
(\% RSD) of the calculated results of the weight percent solids for the SME product are presented in Table 4.

To determine the weight percent dissolved solids, a mixed sample of the SME product was filtered through a Nalgene ${ }^{\circledR}$ filter resulting in a clear supernate. The clear supernate was then mixed and four samples were pipetted into four labeled, pre-weighed PMP $尺$ beakers. The same procedure was followed for the SME supernate samples as for the SME product samples (see above paragraph). The averages, standard deviations (Std. Dev.), and the percent relative standard deviations (\% RSD) of the calculated results of the weight percent dissolved solids for the supernate are presented in Table 4.

Duplicate measurements of the calcined solids were completed in the Shielded Cells Facility for the SME product. Mixed portions of a sample of SME product were pipetted into two pre-weighed alumina crucibles. The crucibles were weighed and then dried overnight at $115^{\circ} \mathrm{C}$ in a drying oven. By removing excess water from the samples, the risk of splattering material from the crucibles when heated to the calcine temperature is minimized. The samples were removed from the drying oven and allowed to cool for $\sim 5$ minutes before they were weighed. The samples were then placed into a muffle furnace and heated to $1000^{\circ} \mathrm{C}$. The samples were held at $1000^{\circ} \mathrm{C}$ for $\sim 2$ hours. The muffle furnace was turned off and the samples were allowed to cool inside of the muffle furnace. The samples were then removed from the muffle furnace, weighed, and the calcined solids were calculated. The averages, standard deviations (Std. Dev.), and the percent relative standard deviations (\% RSD) of the calculated results of the calcine solids for the sludge slurry are presented in Table 4.

Density measurements of the SME product were completed remotely in the Shielded Cells Facility by using heat sealed pipette tips. The pipette tips are first sealed and then calibrated with water to obtain the volume. Four density measurements were completed for the SME product. The sealed pipette tip was first weighed and then a mixed sample of SME product was pipetted into the sealed pipette tip. The sealed pipette tip containing the SME product sample was weighed and a density calculated. The results of the density measurements, along with the standard deviations (Std. Dev.) and the percent relative standard deviations ( $\%$ RSD), are presented in Table 4.

The supernate obtained for the weight percent dissolved solids measurement was also used to complete the SME product supernate density measurements. The same density procedure (see above paragraph) was followed to obtain the results for the SME supernate. The results of the density for the SME supernate sample with the standard deviations (Std. Dev.) and the percent relative standard deviations (\% RSD) are presented in Table 4.

Weight percent insoluble solids, weight percent soluble solids, and the vitrification factor are presented in Table 4. These values are calculated using the weight percent total solids, dissolved solids, and calcined solids results described above. The calculations are shown in Appendix D. 
WSRC-TR-2002-00096

Westinghouse Savannah River Company

Revision 0

Savannah River Technology Center

Table 4 - Weight Percent Solids, Weight Percent Calcined Solids, Density Measurements, and Vitrification Factor for the Tank 40 SME Product

\begin{tabular}{|l|c|c|c|}
\hline & Average & Std. Dev. & \% RSD \\
\hline $\begin{array}{l}\text { Weight Percent Total Solids a, b } \\
\text { (g total dried solids/100 g SME product) }\end{array}$ & $45.3 \mathrm{wt} \%$ & 0.52 & 1.1 \\
\hline $\begin{array}{l}\text { Weight Percent Dissolved Solids a, } \\
\text { (g dissolved solids/100 g SME product } \\
\text { supernate) }\end{array}$ & $7.64 \mathrm{wt} \%$ & 0.062 & 0.81 \\
\hline $\begin{array}{l}\text { Weight Percent Calcined Solids }{ }^{\text {c, }} \text { d } \\
\text { (g calcined solids/100 g SME product) }\end{array}$ & $41.6 \mathrm{wt} \%$ & 1.1 & 2.6 \\
\hline Density of the SME Product $^{\text {e }}$ & $1.36 \mathrm{~g} / \mathrm{mL}$ & 0.035 & 2.6 \\
\hline Density of the SME Product Supernate & $1.04 \mathrm{~g} / \mathrm{mL}$ & 0.0024 & 0.23 \\
\hline $\begin{array}{l}\text { Weight Percent Insoluble Solids } \\
\text { (g insoluble solids/100 g SME product) }\end{array}$ & $40.8 \mathrm{wt} \%$ & 0.57 & 1.4 \\
\hline $\begin{array}{l}\text { Weight Percent Soluble Solids } \\
\text { (g soluble solids/100 g SME product) }\end{array}$ & $4.5 \mathrm{wt} \%$ & 0.77 & 17 \\
\hline $\begin{array}{l}\text { Vitrification Factor } \\
\text { (g glass/mL SME product) }\end{array}$ & 0.566 & 0.021 & 3.7 \\
\hline
\end{tabular}

${ }^{\mathrm{a}}$ The samples for weight percent solids measurements were dried overnight in a drying oven at $115^{\circ} \mathrm{C}$.

${ }^{\mathrm{b}}$ Average of three results.

${ }^{\mathrm{c}}$ Average of two results.

${ }^{\mathrm{d}}$ Samples were calcined at $1000^{\circ} \mathrm{C}$.

${ }^{\mathrm{e}}$ Average of four results.

\subsection{SME Cycle Gas Production}

The SME vessel was purged using air with $0.5 \%$ (nominal) helium. The helium was used as a tracer to calculate flow out of the vessel and gas generation rates. The composition of the gas produced during the SME cycle was measured using a GC located in a hood outside of the SRTC Shielded Cells. The GC was capable of measuring helium, hydrogen, oxygen, nitrogen, carbon dioxide, and nitrous oxide. It should be noted that many of the oxides of nitrogen were likely produced in the SME cycle, but the GC was only capable of measuring nitrous oxide.

Figure 3 shows the hydrogen $\left(\mathrm{H}_{2}\right)$, carbon dioxide $\left(\mathrm{CO}_{2}\right)$, and nitrous oxide $\left(\mathrm{N}_{2} \mathrm{O}\right)$ concentrations during the SME cycle. Table 5 lists the maximum concentrations and generation rates, on a DWPF basis, of $\mathrm{H}_{2}, \mathrm{CO}_{2}$, and $\mathrm{N}_{2} \mathrm{O}$ (see Appendix A for details of conversion from SRTC to DWPF basis). 
Figure 3 - SRTC Scale Hydrogen, Carbon Dioxide, and Nitrous Oxide Concentrations and pH in the Offgas During the SME Cycle

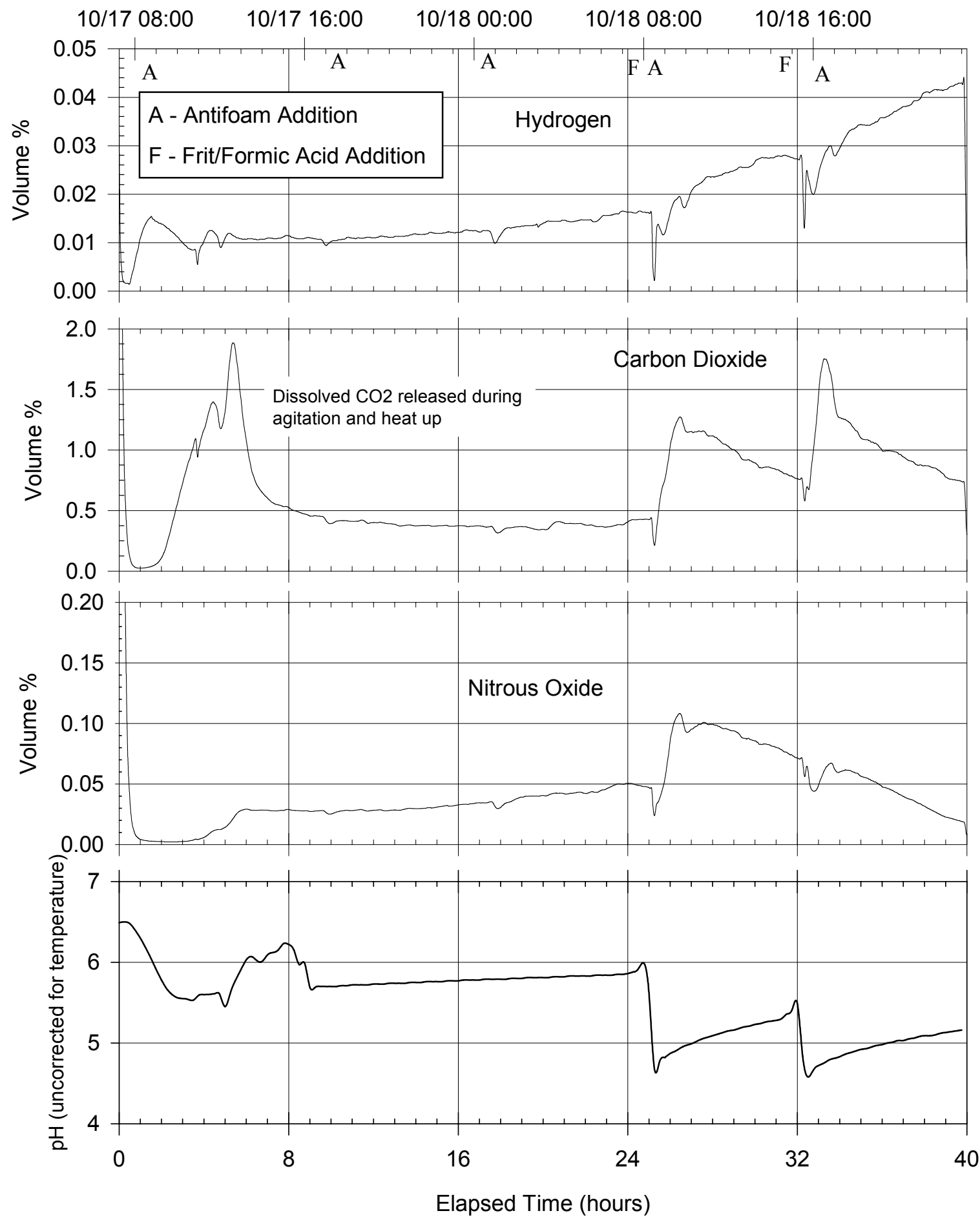


Table 5 - Maximum Hydrogen, Carbon Dioxide, and Nitrous Oxide Generation During the SME Cycle

\begin{tabular}{|l|c|c|c|}
\hline & $\begin{array}{c}\text { SRTC Scale Maximum } \\
\text { Gas Concentration } \\
\text { (Vol. \%) }\end{array}$ & $\begin{array}{c}\text { DWPF Scale Maximum } \\
\text { Gas Concentration } \\
\text { (Vol. \%) }\end{array}$ & $\begin{array}{c}\text { DWPF Scale Maximum } \\
\text { Generation Rate }^{\dagger} \\
\text { (lb/hr) }\end{array}$ \\
\hline Hydrogen & $4.3 \mathrm{E}-02$ & $1.5 \mathrm{E}-02$ & $3.0 \mathrm{E}-03$ \\
\hline Carbon Dioxide & $1.9 \mathrm{E} 00$ & $6.7 \mathrm{E}-01$ & $3.0 \mathrm{E} 00$ \\
\hline Nitrous Oxide & $1.1 \mathrm{E}-01$ & $3.9 \mathrm{E}-02$ & $1.7 \mathrm{E}-01$ \\
\hline
\end{tabular}

${ }^{\dagger}$ Appendix A provides the inputs and assumptions used for calculating gas generation during the SME cycle.

As can be seen from Figure 3, $\mathrm{H}_{2}, \mathrm{CO}_{2}$, and $\mathrm{N}_{2} \mathrm{O}$ were produced following the frit/formic acid additions. The $\mathrm{H}_{2}$ and $\mathrm{CO}_{2}$ were likely the result of catalytic decomposition of formic acid, and the $\mathrm{N}_{2} \mathrm{O}$ may be evidence of reaction between nitric and formic acids (see the discussion of the SME Redox Adjustment Cycle, Section 5.6, for a more detailed discussion of the chemistry).

\subsection{Chemical Composition of Vitrified SME Product}

Table 6 shows the elemental weight percents of the major components in the glass made from the SME product. Table 7 presents the same data, with the elements converted to their oxide forms. Table 7 also shows the calculated composition of the glass based on the blend (see Section 3.2). Except for $\mathrm{Cr}_{2} \mathrm{O}_{3}, \mathrm{CuO}, \mathrm{K}_{2} \mathrm{O}, \mathrm{NiO}, \mathrm{TiO}_{2}$, and $\mathrm{ZrO}_{2}$, the measured values agree well with the calculated. As mentioned earlier, the glass was ground for analysis in a stainless steel grinder. This could account for the higher than predicted chromium and nickel values. Copper contamination could have resulted from the brass sieve used to sieve the glass for dissolution. Potassium, titanium, and zirconium are minor constituents in the glass, and the difference between predicted and analyzed result could be analytical error.

Table 6 - Required Elements (excluding oxygen) for Checking the SME Acceptability for the Tank 40 /Frit 200 SRTC Vitrified SME Product

\begin{tabular}{|c|c|c|c|}
\hline Element & Weight Percent ${ }^{*}$ a & Element & Weight Percent ${ }^{*}$, a \\
\hline $\mathrm{Al}$ & $2.26 \mathrm{E} 00( \pm 7.3 \mathrm{E}-02,3.2 \mathrm{E} 00)$ & $\mathrm{Mg}$ & $1.50 \mathrm{E} 00( \pm 5.7 \mathrm{E}-02,3.8 \mathrm{E} 00)$ \\
\hline $\mathrm{B}^{\mathrm{c}}$ & $2.55 \mathrm{E} 00( \pm 3.9 \mathrm{E}-02,1.5 \mathrm{E} 00)$ & $\mathrm{Mn}$ & $1.07 \mathrm{E} 00( \pm 3.6 \mathrm{E}-02,3.4 \mathrm{E} 00)$ \\
\hline $\mathrm{Ca}^{\mathrm{c}}$ & $9.27 \mathrm{E}-01( \pm 4.6 \mathrm{E}-02,5.0 \mathrm{E} 00)$ & $\mathrm{Na}^{\mathrm{c}}$ & $8.83 \mathrm{E} 00( \pm 4.4 \mathrm{E}-02,4.9 \mathrm{E}-01)$ \\
\hline $\mathrm{Cr}^{\mathrm{b}}$ & $2.26 \mathrm{E}-01( \pm 1.6 \mathrm{E}-02,7.2 \mathrm{E} 00)$ & $\mathrm{Ni}^{\mathrm{b}}$ & $4.74 \mathrm{E}-01( \pm 1.3 \mathrm{E}-02,2.7 \mathrm{E} 00)$ \\
\hline $\mathrm{Cu}^{\mathrm{c}}$ & $7.14 \mathrm{E}-02( \pm 1.2 \mathrm{E}-03,1.7 \mathrm{E} 00)$ & $\mathrm{P}$ & $2.46 \mathrm{E}-01( \pm 1.5 \mathrm{E}-02,5.9 \mathrm{E} 00)$ \\
\hline $\mathrm{Fe}^{\mathrm{b}, \mathrm{c}}$ & $8.26 \mathrm{E} 00( \pm 1.6 \mathrm{E}-01,2.0 \mathrm{E} 00)$ & $\mathrm{Si}^{\mathrm{c}}$ & $2.48 \mathrm{E} 01( \pm 3.5 \mathrm{E}-01,1.4 \mathrm{E} 00)$ \\
\hline $\mathrm{K}^{\mathrm{d}}$ & $1.36 \mathrm{E}-01( \pm 6.8 \mathrm{E}-04,5.0 \mathrm{E}-01)$ & $\mathrm{Ti}$ & $4.87 \mathrm{E}-02( \pm 2.3 \mathrm{E}-03,4.8 \mathrm{E} 00)$ \\
\hline \multirow[t]{2}{*}{$\mathrm{Li}$} & $1.63 \mathrm{E} 00( \pm 2.7 \mathrm{E}-02,1.6 \mathrm{E} 00)$ & $\mathrm{U}^{\mathrm{c}, \mathrm{e}}$ & $2.53 \mathrm{E} 00( \pm 5.7 \mathrm{E}-02,2.3 \mathrm{E} 00)$ \\
\hline & & $\mathrm{Zr}^{\mathrm{c}}$ & $9.45 \mathrm{E}-02( \pm 2.7 \mathrm{E}-03,2.9 \mathrm{E} 00)$ \\
\hline
\end{tabular}

The SME product was vitrified at $1150^{\circ} \mathrm{C}$. The resulting glass was dissolved. The results are presented as elemental weight percent in the glass.

${ }^{a}$ Results are determined by Inductively Coupled Plasma-Emission Spectroscopy unless otherwise indicated and are the average of eight sample results of dissolved glass. The standard deviation and the percent relative standard deviation are presented in parentheses next to each value.

${ }^{\mathrm{b}}$ Slightly contaminated with $\mathrm{Cr}, \mathrm{Ni}$, and $\mathrm{Fe}$ from the stainless steel Tekmar grinder used to grind the glass. Calculated values for $\mathrm{Cr}, \mathrm{Ni}$, and $\mathrm{Fe}$ for the blend of Tank 40 and Frit 200 were 0.054 wt. \%, 0.408 wt. \%, and 8.08 wt\% respectively ${ }^{13}$

${ }^{c}$ Average of four results.

${ }^{\mathrm{d}}$ Results determined by Atomic Adsorption method.

${ }^{\mathrm{e}}$ Results determined by Inductively Coupled Plasma-Mass Spectroscopy method. 
Table 7 - Average Measured and Calculated Composition (Major Oxide Wt\%) of the Vitrified SME Product

\begin{tabular}{|c|c|c|}
\hline Oxide & $\begin{array}{c}\text { Measured } \\
\text { Composition } \\
\text { (wt\%) }\end{array}$ & $\begin{array}{c}\text { Calculated } \\
\text { Composition } \\
\text { (wt\%) }\end{array}$ \\
\hline $\mathrm{Al}_{2} \mathrm{O}_{3}$ & $4.27 \mathrm{E}+00$ & $4.27 \mathrm{E}+00$ \\
\hline $\mathrm{B}_{2} \mathrm{O}_{3}$ & $8.21 \mathrm{E}+00$ & $8.22 \mathrm{E}+00$ \\
\hline $\mathrm{CaO}$ & $1.30 \mathrm{E}+00$ & $1.28 \mathrm{E}+00$ \\
\hline $\mathrm{Cr}_{2} \mathrm{O}_{3}$ & $3.30 \mathrm{E}-01$ & $7.89 \mathrm{E}-02$ \\
\hline $\mathrm{CuO}$ & $8.94 \mathrm{E}-02$ & $1.88 \mathrm{E}-02$ \\
\hline $\mathrm{Fe}_{2} \mathrm{O}_{3}$ & $1.18 \mathrm{E}+01$ & $1.16 \mathrm{E}+01$ \\
\hline $\mathrm{K}_{2} \mathrm{O}$ & $1.64 \mathrm{E}-01$ & $1.17 \mathrm{E}-01$ \\
\hline $\mathrm{Li}_{2} \mathrm{O}$ & $3.51 \mathrm{E}+00$ & $3.45 \mathrm{E}+00$ \\
\hline $\mathrm{MgO} \mathrm{O}$ & $2.49 \mathrm{E}+00$ & $2.43 \mathrm{E}+00$ \\
\hline $\mathrm{MnO}+38 \mathrm{E}+00$ & $1.38 \mathrm{E}+00$ \\
\hline $\mathrm{Na}_{2} \mathrm{O}$ & $1.19 \mathrm{E}+01$ & $1.16 \mathrm{E}+01$ \\
\hline $\mathrm{NiO}_{i}$ & $6.03 \mathrm{E}-01$ & $5.19 \mathrm{E}-01$ \\
\hline $\mathrm{SiO}_{2}$ & $5.31 \mathrm{E}+01$ & $4.98 \mathrm{E}+01$ \\
\hline $\mathrm{TiO}_{2}$ & $8.12 \mathrm{E}-02$ & $4.84 \mathrm{E}-02$ \\
\hline $\mathrm{UO} 2$ & $2.87 \mathrm{E}+00$ & $2.80 \mathrm{E}+00$ \\
\hline $\mathrm{ZrO}_{2}$ & $1.28 \mathrm{E}-01$ & $8.10 \mathrm{E}-03$ \\
\hline $\mathrm{Total}$ & $1.02 \mathrm{E}+02$ & $9.76 \mathrm{E}+01$ \\
\hline
\end{tabular}

\subsection{Product Consistency Test (PCT)}

The PCT is a standard ASTM leach test ${ }^{15}$. The test is a crushed glass leach test using ASTM Type I water. It was performed in Cell 14 on quadruplicate samples of crushed, ground Tank 40/Frit 200 glass following the ASTM-1285-97 procedure. The test, which was performed at $90^{\circ} \mathrm{C}$ for seven days, included the appropriate blanks and standards (Approved Reference Material-1 (ARM-1) glass) and a multi element analytical standard. The results for the ARM-1 standard glass and the blanks indicated that the test was acceptable. The Tank 40/Frit 320 glass was included in this PCT and the results for the standards and blanks are given in Appendix B of the Tank 40/Frit 320 Report $^{17}$. The Environmental Assessment (EA) glass was included in the PCT test in order to compare its durability with that of the Tank 40/Frit 200 glass.

The concentrations of several elements and radionuclides in the leachates were measured using Inductively Coupled Plasma - Emission Spectroscopy (ICP-ES), Inductively Coupled Plasma - Mass Spectroscopy (ICP-MS), and radioactive counting techniques. The PCT procedure requires the measurement of $\mathrm{Na}, \mathrm{Li}$, and $\mathrm{B}$, because these are the major elements in the glass that are the best indicators of the durability of the glass. We measured the concentrations of radionuclides detected in 
the leachates to determine if any had normalized releases larger than those for $\mathrm{Na}, \mathrm{B}$, or $\mathrm{Li}$. The measured concentrations of the radionuclides were used along with their measured concentrations in the glass to calculate the average normalized releases in terms of grams of glass dissolved per liter of leachate based on a specific element or radionuclide in the glass. The normalized releases were calculated using the following equation.

$$
N R_{i}=\frac{C_{i}}{F_{i} \cdot 10}
$$

where $N R_{i}=$ the normalized release based on element i

$C_{i}=$ the concentration $(\mathrm{ppm})$ of $i$ in the leachate

$F_{i}=$ the weight percent of $i$ in the glass.

Results are presented for boron, sodium, lithium, and silicon in Table 8 as the average of the normalized releases. Values for the $\mathrm{pH}$ of the leachates are also presented. Values predicted using the PCT/chemical composition correlations from THERMO ${ }^{18}$ are also presented. The average measured values for the EA glass are also presented along with published values ${ }^{16}$. Silicon is not required by the WAPS ${ }^{19}$ but is provided because it is a major component of the glass. The leachate $\mathrm{pH}$ was measured as part of the PCT protocol and provides a secondary indication of glass durability. Typically, the higher the leachate $\mathrm{pH}$, the lower the durability.

Table 8 - Normalized PCT Results for Major Nonradioactive Element in Tank 40 Frit 200 Glass and for the Environmental Assessment Glass

\begin{tabular}{|c|c|c|c|c|c|}
\hline Element & $\begin{array}{l}\text { Measured }^{\text {a }} \\
(\mathrm{g} \text { Glass/L) }\end{array}$ & $\begin{array}{c}\text { Predicted }^{b} \\
(\mathrm{~g} / \mathrm{L})\end{array}$ & $\begin{array}{l}\text { Measured } \\
\text { /Predicted }\end{array}$ & $\begin{array}{c}\text { Measured EA }{ }^{a} \\
(\mathrm{~g} / \mathrm{L})\end{array}$ & $\begin{array}{c}\text { Published } \\
\text { EA }^{\mathrm{c}} \\
(\mathrm{g} / \mathrm{L}) \\
\end{array}$ \\
\hline B & $0.887 \pm 0.011$ & 0.64 & 1.4 & $18.6 \pm 0.5(2.5)$ & 16.7 \\
\hline $\mathrm{Na}$ & $0.809 \pm 0.009(1.2)$ & 0.64 & 1.3 & $14.0 \pm 0.3(2.2)$ & 13.3 \\
\hline $\mathrm{Li}$ & $0.867 \pm 0.008$ & 0.68 & 1.3 & $9.96 \pm 0.19(1.9)$ & 9.57 \\
\hline $\mathrm{Si}$ & $0.504 \pm 0.004(0.80)$ & N/A & N/A & $4.3 \pm 0.1(2.1)$ & 3.9 \\
\hline $\mathrm{pH}$ & 9.9 & N/A & N/A & 11.6 & 11.9 \\
\hline
\end{tabular}

${ }^{\text {a }}$ Based on quadruplicate samples of the Tank 40/Frit 200 and EA glass. For each glass, the standard deviation of the mean is given as the uncertainty along with the percent relative standard deviation (in parenthesis) based on the leachate analyses only.

${ }^{\mathrm{b}}$ Predicted by Reference 27.

${ }^{\mathrm{c}}$ Published results for EA glass are taken from Reference 16.

The normalized elemental release ranges reported in Table 8 indicate that the Tank 40/Frit 200 glass met the PCT acceptance criterion as defined in the WAPS ${ }^{19}$. This criterion states that the durability of the glass produced must be at least two standard deviations lower than the EA glass ${ }^{16}$ in a PCT test. The fact that the Tank 40/Frit 200 glass is more durable than the EA glass is also indicated by the lower final $\mathrm{pH}$ value for the leachates of the Tank 40/Frit 200 glass. For some reason the measured releases for boron, lithium, and sodium were all slightly higher than the the published values for the EA glass even though the ARM glass releases were acceptable (see Reference 18). The agreement between the measured and predicted normalized releases in Table 8 for the Tank 40 Frit 200 glass is similar to that observed for the Frit 320 glass $^{18}$. 
Table 9 presents the normalized releases calculated for several radionuclides in the Tank 40/Frit 200 glass. Results for $\mathrm{B}, \mathrm{Na}, \mathrm{Li}$, and $\mathrm{Si}$ are repeated in Table 9 for ease in comparing their results with those for the radionuclides. Weight percents of the elements in the glass along with their concentrations in the leachates are presented to illustrate the large range in these measured values ( 24.8 to $8.9 \mathrm{E}-05 \mathrm{wt} \%$ and 125 to $4.8 \mathrm{E}-05 \mathrm{ppm}$, respectively).

\section{Table 9 - Normalized PCT Results for Major Nonradioactive Elements and Several Radionuclides in Tank 40 Frit 200 Glass ${ }^{\text {a }}$}

\begin{tabular}{|c|c|c|c|}
\hline Element & $\begin{array}{c}\text { Wt. \% In } \\
\text { Glass } \\
\end{array}$ & $\begin{array}{c}\text { Leachate } \\
\text { Concentration } \\
\text { (ppm) }\end{array}$ & $\begin{array}{c}\text { Normalized Release } \\
\text { (Grams Glass/L) }\end{array}$ \\
\hline $\mathrm{B}$ & 2.55 & 22.6 & $0.89(1.2 \%)$ \\
\hline $\mathrm{Na}$ & 8.83 & 71.4 & $0.81(1.1 \%)$ \\
\hline $\mathrm{Li}$ & 1.63 & 14.1 & $0.87(0.9 \%)$ \\
\hline $\mathrm{Si}$ & 24.8 & 125. & $0.50(0.80 \%)$ \\
\hline Sr-90 & $1.1 \mathrm{E}-03$ & $8.5 \mathrm{E}-05^{\mathrm{b}}$ & $0.0077(9.6 \%)$ \\
\hline Tc-99 & $2.3 \mathrm{E}-04$ & $2.1 \mathrm{E}-03^{\mathrm{c}}$ & $0.91(2.2 \%)$ \\
\hline Cs-137 & 8.9E-05 & $1.45 \mathrm{E}-04^{\mathrm{d}}$ & $0.16(5.1 \%)$ \\
\hline Th-232 & $6.5 \mathrm{E}-03$ & $4.0 \mathrm{E}-03^{\mathrm{c}}$ & $0.061(12 \%)$ \\
\hline $\mathrm{Np}-237$ & 4.6E-04 & $1.1 \mathrm{E}-04^{\mathrm{c}}$ & $0.024(58 \%)$ \\
\hline U-238 & 2.53 & $3.73^{c}$ & $0.15(8.7 \%)$ \\
\hline U-235 & $9.7 \mathrm{E}-03$ & $1.6 \mathrm{E}-02^{\mathrm{c}}$ & $0.16(4.8 \%)$ \\
\hline Pu-239 & $3.4 \mathrm{E}-03$ & $1.4 \mathrm{E}-03^{\mathrm{c}}$ & $0.041(5.4 \%)$ \\
\hline $\mathrm{Pu}-240$ & $3.2 \mathrm{E}-04$ & $1.3 \mathrm{E}-03^{\mathrm{c}}$ & $0.041(8.7 \%)$ \\
\hline Am-241 & $2.7 \mathrm{E}-04$ & $4.8 \mathrm{E}-05^{\mathrm{d}}$ & $0.018(6.0 \%)$ \\
\hline
\end{tabular}

${ }^{a}$ Based on quadruplicate samples of the Tank 40/Frit 200. For the normalized releases, the standard deviation of the mean based only on the leachate analyses is given in parenthesis.

${ }^{\mathrm{b}}$ Measured by beta counting after special separation.

${ }^{\mathrm{c}}$ Measured by ICP-MS

${ }^{\mathrm{d}}$ Measured by gamma counting.

Note that the only radionuclide that has a normalized release similar to $\mathrm{B}, \mathrm{Na}$, or $\mathrm{Li}$ is $\mathrm{Tc}-99$. This has been observed in another PCT test with a DWPF type glass ${ }^{20}$ and a leach test using a small monolith of a DWPF type glass doped with Tc- $99^{21}$.

Normalized releases for $\mathrm{U}$ and $\mathrm{Cs}-137$ are nominally 5-6X lower than those for B, Na, or Li, while the other radionuclides have even lower releases. It should be noted that in this PCT test, the vessels were not rinsed with acid after the test to strip those radionuclides that may have sorbed on the walls of the vessel. Thus normalized releases for some of the radionuclides that have low solubilities could be higher than what is reported in Table 9. Such radionuclides are $\mathrm{Sr}-90$ and $\mathrm{Pu}$. From the data in Table 9, the normalized release for $\mathrm{Sr}-90$ is $\sim 100 \mathrm{X}$ lower than those for $\mathrm{B}, \mathrm{Na}$, or $\mathrm{Li}$, while that for $\mathrm{Pu}$ is $\sim 20 \mathrm{X}$ lower. In a PCT at $\mathrm{SRS}^{22}$ with two different radioactive glasses where the vessels were acid stripped, the normalized releases for Sr-90 were 25 to $250 \mathrm{X}$ lower than those for B, Na, or Li. For $\mathrm{Pu}$, the releases were 4 to $10 \mathrm{X}$ lower. Results for $\mathrm{Cs}-137$ were $4-5 \mathrm{X}$ lower than those for $\mathrm{B}, \mathrm{Na}$, or 
$\mathrm{Li}$, in agreement with the results calculated from Table 9. Thus it appears that sorption on the vessel walls can be a factor but not large enough to make the measured releases for these elements to be as large as those for B, Na, or Li. Sorption on the walls has been shown not to occur with Tc- $99^{21}$. Thus its release given in Table 9 is the total release for Tc-99. Based on the data in Table 9 and the results published in Reference 22, it can be said that of all the radionuclides measured, only Tc-99 has a release rate similar to $\mathrm{B}, \mathrm{Na}$, or $\mathrm{Li}$, the elements that are to be measured in the PCT.

\subsection{Examination of the Tank 40/Frit 200 Glass by Scanning Electron Microscopy}

Scanning Electron Microscopy (SEM) with X-ray Energy Dispersive Spectroscopy (EDS) were used to examine the vitrified SME product. One sample of approximately 0.015 grams of vitrified SME product was prepared for analysis. The sample was from glass that had been ground, washed, and sieved for the PCT. A typical micrograph for the sample is shown in Figure 4. EDS analysis of the sample showed that the main glass components were Si and Fe (see Figure 5). The arrow in Figure 4 indicates a particle whose image is shown in Figure 6 at a larger magnification.

Figure 4 - SEM Micrographs of the Vitrified SME Product Sample at 50x

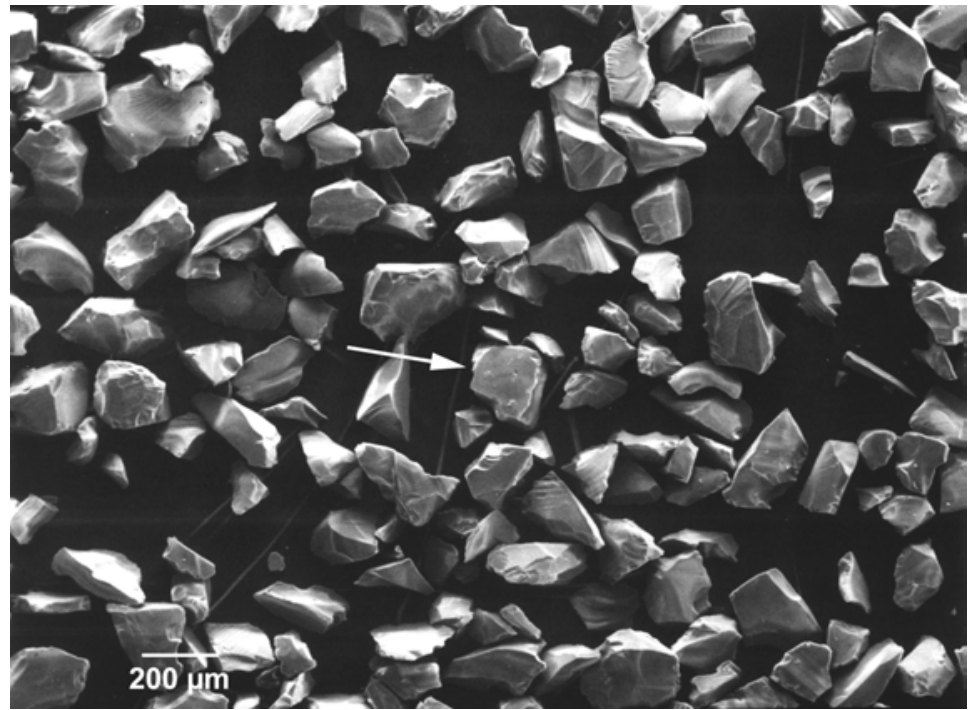


Figure 5 - EDS Spectrum of Vitrified SME Product ${ }^{\dagger}$

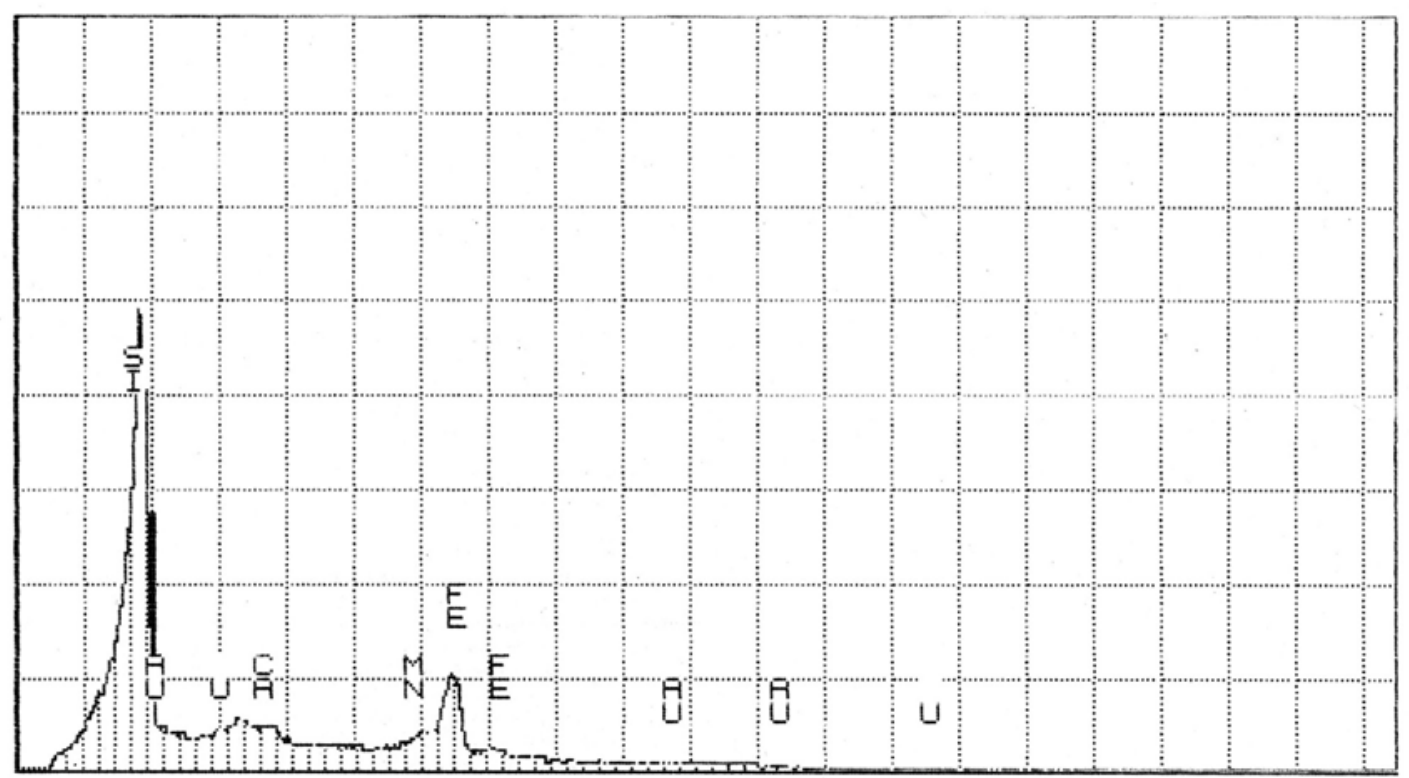

${ }^{\dagger} \mathrm{The} \mathrm{Au}$ in the spectra is due to the Au alloy used to coat the samples for analysis.

Figure 6 is a more magnified view of the particle indicated by the arrow in Figure 4. This micrograph shows smaller particles adhering to the surface. The majority of these smaller particles are glass and are not stainless steel; however, two of the particles (indicated by the arrows in Figure 6) are stainless steel. Apparently, as evidenced by the measured and calculated compositions in Table 7, this slight stainless steel contamination was sufficient to increase the $\mathrm{Cr}$ above that predicted by PCCS from the composition of the blend.

No crystals were detected in any of the particles examined by SEM.

Figure 6 - SEM Micrograph of the Representative Particle Identified in Figure 4 at 500x

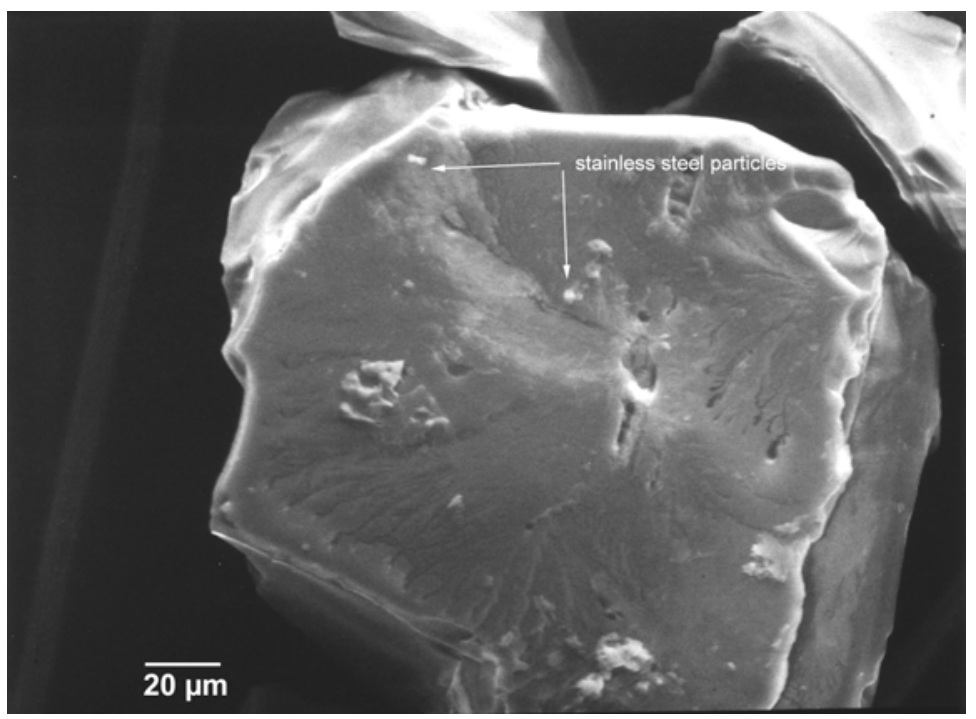


WSRC-TR-2002-00096

Revision 0
Westinghouse Savannah River Company Savannah River Technology Center

\subsection{SME Redox Adjustment Cycle}

SRTC scale gas concentration and $\mathrm{pH}$ during the SME Redox Adjustment Cycle are presented graphically in Figure 7.

Figure 7 - SRTC Scale Hydrogen, Carbon Dioxide, and Nitrous Oxide Concentrations and pH During the SME Redox Adjustment Cycle
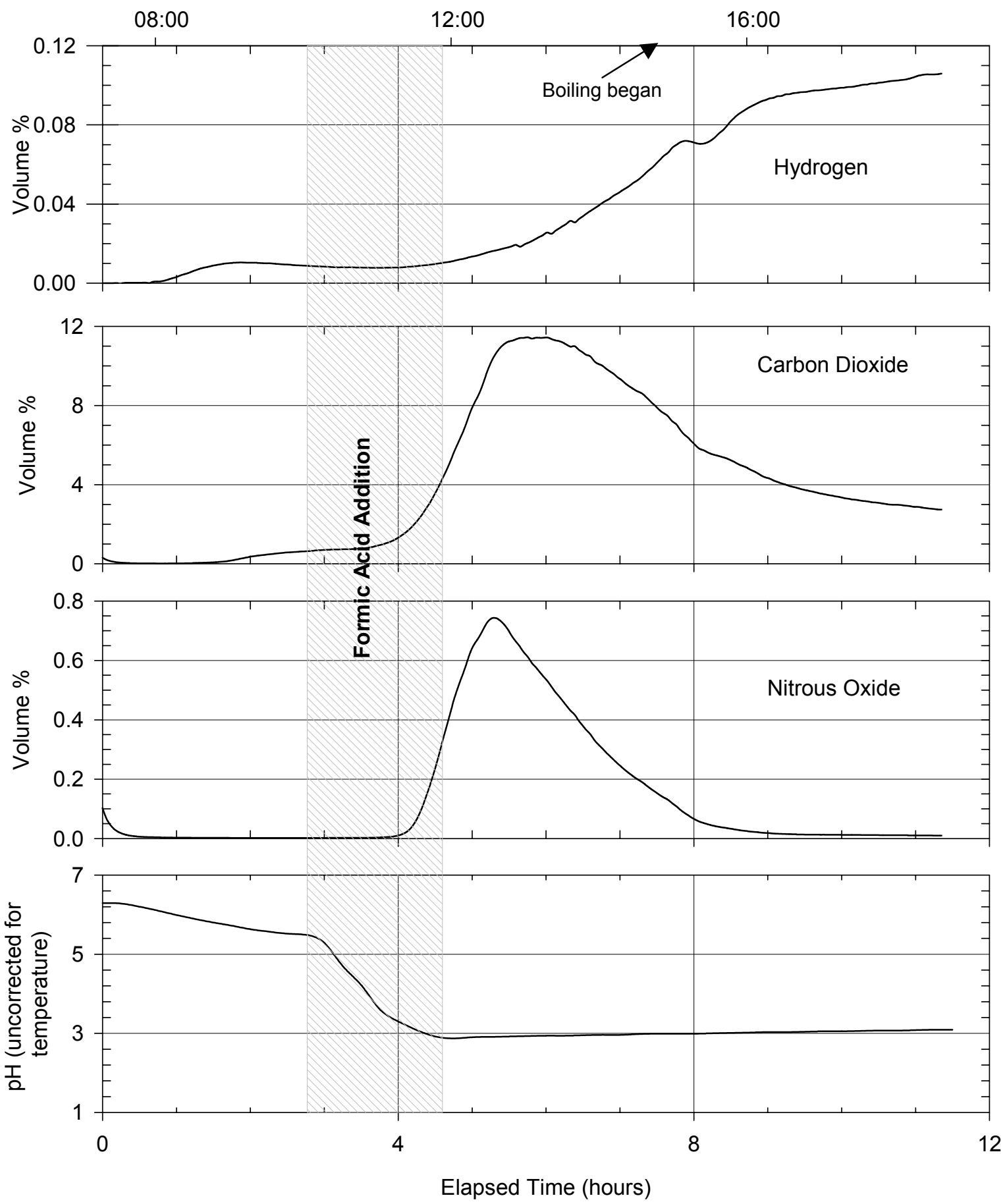
As can be seen from Figure 7, as formic acid was added to the vessel, carbon dioxide and nitrous oxide evolved, and $\mathrm{pH}$ decreased. Hydrogen generation increased after the formic acid addition was complete and as the vessel temperature was increased from $\sim 90^{\circ} \mathrm{C}$ to boiling. Maximum gas concentrations and generation rates are presented in Table 10. A description of calculations is given in Appendix A.

Table 10 - Maximum Observed Gas Concentrations and Generation Rates During the SRTC SME Redox Cycle

\begin{tabular}{|l|c|c|c|}
\hline Gas & $\begin{array}{c}\text { SRTC Scale Maximum Gas } \\
\text { Concentration (Volume \%) }\end{array}$ & $\begin{array}{c}\text { DWPF Scale Maximum } \\
\text { Gas Concentration } \\
\text { (Volume \%) }\end{array}$ & $\begin{array}{c}\text { DWPF Scale Maximum } \\
\text { Gas Generation Rate } \\
\text { (lb/hr) }\end{array}$ \\
\hline Hydrogen & 0.11 & 0.036 & 0.0071 \\
\hline Carbon Dioxide & 11.4 & 3.7 & 20.6 \\
\hline Nitrous Oxide & 0.74 & 0.24 & 1.3 \\
\hline
\end{tabular}

The primary reaction for hydrogen generation is:

$\mathrm{HCOOH} \stackrel{\text { catalyst }}{\longrightarrow} \mathrm{H}_{2}+\mathrm{CO}_{2}$

This reaction is highly dependent on nitrite content (hydrogen evolves after nitrite is destroyed), the vessel temperature, and the amount of excess formic $\operatorname{acid}^{23}$. Since most of the nitrite in the SME product was destroyed in the SRAT cycle, the nitrite content did not delay the production of hydrogen. This is confirmed by the fact that hydrogen concentration was rising as nitrous oxide concentration was rising, as seen in Figure 7. During the SRAT cycle, the hydrogen concentration did not increase until after the nitrous oxide concentration peaked.

The factors contributing to hydrogen generation during the redox cycle were vessel temperature and the amount of formic acid added to the vessel. The hydrogen concentration remained fairly constant until completion of the formic acid addition, and then increased as the vessel was heated to boiling.

The large amounts of carbon dioxide and nitrous oxide are likely the result of a denitration reaction (a reaction between nitric acid and formic acid). As $\mathrm{pH}$ drops to 3 with a formic acid concentration greater than nitric acid concentration, the following reaction can occur ${ }^{24}$ :

$2 \mathrm{HNO}_{3}+4 \mathrm{HCOOH} \rightarrow \mathrm{N}_{2} \mathrm{O}+4 \mathrm{CO}_{2}+5 \mathrm{H}_{2} \mathrm{O}$

It is believed this reaction was slowing before the end of the reflux period. Nitrous oxide concentration was approaching zero, and $\mathrm{pH}$ was beginning to increase.

\subsection{ACCEPTABILITY OF THE GLASS USING PRODUCT COMPOSITION CONTROL SYSTEM (PCCS)}

WD Engineering evaluated the acceptability of the Tank 40/Frit 200 glass based on two compositions. One was the glass composition calculated from the SME blend and the other was the measured composition of the final glass. 
The acceptability of the glass from the SME blend was documented by WD Engineering ${ }^{13}$. The SME blending calculations determined the amount of Frit 200 to be added to the Macrobatch 3 SRAT Product. The SME blend, based on a calculated composition of the glass, met all the PCCS constraints (including that for $\mathrm{Cr}$ ) except the homogeneity constraint. However, the calculated composition for the glass contained a concentration of aluminum oxide greater than $4 \mathrm{wt} \%$. This aluminum oxide concentration was sufficient to reduce the application of the homogeneity constraint from the MAR to the $\mathrm{PAR}^{25,26}$.

WD Engineering also performed a SME acceptability calculation based on the measured composition of vitrified SME product ${ }^{27}$. All constraints were met with the exception of the chromium constraint. As was noted in Section 5.5, there was chromium contamination from the grinder used to prepare the glass for PCT . This contamination was detected in the SEM analysis. In the SME blending calculations $^{12}$ the predicted composition of the glass did meet the Cr constraint.

\subsection{QUALITY ASSURANCE}

The following certified NIST traceable standard gases (from Air Liquide) were used to calibrate the GC for the SME and Redox Adjustment cycles:

$\begin{array}{lllllll} & \mathrm{He} & \mathrm{H}_{2} & \mathrm{O}_{2} & \mathrm{~N}_{2} & \frac{\mathrm{O}}{\mathrm{CO}_{2}} & \mathrm{~N}_{2} \\ \text { CalGas 1 } & 0.80 & 1.00 & 12.00 & 15.00 & 25.00 & \text { Balance } \\ \text { CalGas 2 } & 0.20 & 0.10 & 20.00 & 0.10 & 1.00 & \text { Balance }\end{array}$

Each calibration gas was sampled until a steady reading on the GC was obtained to establish a calibration curve for each species immediately before each cycle.

All samples generated in the Shielded Cells for this task were tracked per L1 2.21 Procedure, "Radioactive Sample Receiving, Labeling and Tracking". All sludge dissolution samples were submitted with standards to check that dissolutions were complete and the analytical procedures were performed correctly ${ }^{8,9}$.

Data are recorded in notebooks WSRC-NB-2000-00166 ${ }^{28}$, WSRC-NB-2001-00162 ${ }^{29}$, and WSRC-NB-2001-00163 $3^{30}$.

\subsection{CONCLUSIONS}

Based on the data presented in this report, the following conclusions can be drawn from the Tank40/Frit 200 SME cycle, vitrification, and formic acid addition cycle in the SRTC Shielded Cells:

- The maximum hydrogen generation rate during the SME cycle $(0.0030 \mathrm{lb} / \mathrm{hr}$ on a DWPF basis $)$ was well below the DWPF hydrogen design basis rate of $0.223 \mathrm{lb} / \mathrm{hr}$.

- For the major elements, the measured composition of the glass was very close to the composition calculated by WD Engineering. The calculated composition of the glass from SME blending calculations met all the PCCS constraints, except homogeneity at the MAR. The measured composition failed the $\mathrm{Cr}$ constraint because of $\mathrm{Cr}$ contamination from the stainless steel grinder. 
- The glass produced from this demonstration met the durability acceptance criterion as defined in WAPS $^{19}$. The releases of $\mathrm{B}, \mathrm{Na}$, and $\mathrm{Li}$ in the PCT were all significantly less than their respective releases from the EA glass.

- In the PCT, the only radionuclide that had a normalized release equal to that for $\mathrm{B}, \mathrm{Li}$, or $\mathrm{Na}$ was Tc-99. All other radionuclides detected in the leachates (Sr-90, Cs-137, Th-232, Np-237, U, Pu, and Am-241) had lower normalized releases.

- The glass contained no crystals as determined by SEM examination; however, SEM is a surface analysis technique. (The glass was too radioactive for analysis by X-ray diffraction which is a bulk analysis technique.)

- The maximum hydrogen generation rate during the Redox Adjustment cycle $(0.0071 \mathrm{lb} / \mathrm{hr}$ on a DWPF basis) was well below the DWPF hydrogen design basis rate of $0.223 \mathrm{lb} / \mathrm{hr}$.

- During the Redox Adjustment cycle, there was evidence of denitration after the formic acid addition.

\subsection{REFERENCES}

${ }^{1}$ N.E. Bibler and J.W. Ray, "Macrobatch 3 Acceptance Evaluation - Radionuclide Concentrations in the Washed Sludge Slurry for Macrobatch 3 (Sludge Batch 2) (U), WSRC-RP-2001-00970, Rev. 1, February 21, 2002.

${ }^{2}$ T.L. Fellinger, N.E. Bibler, J.M. Pareizs, A.D. Cozzi, and C.L. Crawford, "Macrobatch 3 Acceptance Evaluation - Data from the Shielded Cells Demonstration of Defense Waste Processing Facility's Feed Preparation Cycles for Macrobatch 3 (Sludge Batch 2) (U)", WSRC-RP-2001-00971, Rev. 0, November 1, 2001.

${ }^{3}$ T.L. Fellinger, N.E. Bibler, J.M. Pareizs, A.D. Cozzi, and C.L. Crawford, "Macrobatch 3 Acceptance Evaluation - Data from the Shielded Cells Demonstration of Defense Waste Processing Facility's SME Feed Preparation Cycle for Macrobatch 3 (Sludge Batch 2) (U)", WSRC-RP-200101016, Rev. 0, November 19, 2001.

${ }^{4}$ D.C. Koopman, "Sludge Batch 2 (Macrobatch 3) Flow-sheet Studies with Simulants (U), WSRCTR-2000-00398, Revision Rev. 0, October 2000.

${ }^{5}$ M.A. Rios-Armstrong, Technical Task Request, HLW/DWPF/TTR-00-0016, Rev. 1, September 7, 2000 .

${ }^{6}$ Westinghouse Savannah River Company, "DWPF Waste Form Compliance Plan (U)", WSRC-IM91-116-0, Rev. 5, (11/95).

${ }^{7}$ C.C. Herman, T.B. Edwards, and D.M. Marsh, "Summary of Results for Expanded Macrobatch 3 Variability Study (U)”, WSRC-TR-2001-00511, Rev. 0, October 31, 2001.

${ }^{8}$ T.L. Fellinger, "Technical and QA Plan: Shielded Cells Confirmation Run Using Macro Batch 3 (Sludge Batch 2) Radioactive Sludge and Frit 200 (U), WSRC-RP-2000-00698, Rev. 0, November 3, 2000 . 
${ }^{9}$ T.L. Fellinger, "Analytical Study Plan for the Qualification of Macro Batch 3 Radioactive Sludge Slurry (U)”, WSRC-RP-2000-00782, Rev. 0, April 30, 2001.

${ }^{10}$ T.L. Fellinger, "Run Plan for the Tank 40 Radioactive Sludge and Frit 200 Confirmation Run and a Crucible Melt with the SRAT Product and Frit 320 in the Shielded Cells Facility (U)", WSRC-RP2000-00781, Rev. 0, September 25, 2001.

${ }^{11}$ T.L. Fellinger, N.E. Bibler, J.M. Pareizs, A.D. Cozzi, and C.L. Crawford, "Confirmation Run of the DWPF SRAT Cycle Using the Sludge-Only Flowsheet with Tank 40 Radioactive Sludge and Frit 200 in the Shielded Cells Facility (U) “, WSRC-TR-2002-00076, to be published.

${ }^{12}$ T.L. Fellinger, "Composition of Tank 40 Sludge Batch 2 SRAT Product for SME Blending Calculations", SRT-GPD-2001-00100, Rev 0, October 15, 2001.

${ }^{13}$ M.A. Rios-Armstrong, "SME Blending for Macrobatch 3 Shielded Cells Run (U)," Interoffice Memorandum HLW-DEN-2001-00240, October 16, 2001.

${ }^{14}$ G.L. Smith, "Characterization of Analytical Reference Glass-1 (ARG-1)”, PNL-8992, Pacific Northwest Laboratory, Richland, WA (1993).

15 "Standard Test Methods for Determining Chemical Durability of Nuclear, Hazardous, and Mixed Waste Glasses: The Product Consistency Test (PCT)", ASTM C 1285-97, American Society for Testing and Materials (1998).

${ }^{16}$ C.M. Jantzen, N.E. Bibler, D.C. Beam, C.L. Crawford, and M.A. Pickett, "Characterization of the Defense Waste Processing Facility (DWPF) Environmental Assessment (EA) Glass Standard Reference Material (U)", WSRC-TR-92-346, Rev. 1, (6/94).

${ }^{17}$ A.D. Cozzi, N.E. Bibler, T.L. Fellinger, J.M. Pareizs, and K.G. Brown "Vitrification of the DWPF SRAT Cycle of the Sludge-Only Flowsheet with Tank 40 Radioactive Sludge using Frit 320 in the Shielded Cells Facility", WSRC-RP-2002-00022, Rev. 0 (2002).

${ }^{18}$ C.M. Jantzen, J.B. Pickett, K.G. Brown, T.B. Edwards, and D.C. Beam, "Process/Product Models for the Defense Waste Processing Facility (DWPF): Part I. Predicting Glass Durability From Composition Using Thermodynamic Hydration Energy Reaction Model (THERMO) (U)", WSRCTR-93-672, Rev. 1, September 28, 1995.

${ }^{19}$ Office of Environmental Restoration and Waste Management, "Waste Acceptance Product Specifications for Vitrified High-Level Waste Forms", USDOE Document DOE/EM-0093, Rev. 2, (12/96).

${ }^{20}$ W. L. Ebert, S. F. Wolf, and J. K. Bates, "The Release of Tc-99 from Defense Waste Processing Facility Glasses," Mat. Res. Soc. Symp. Proc., Vol. 412, pp. 221-227, Materials Research Society, Pittsburgh, PA (1996).

${ }^{21}$ N. E. Bibler and A. R. Jurgensen, "Leaching Tc-99 from SRP Glasses and Simulated Tuff and Salt Groundwaters,” Mat. Res. Soc. Symp. Proc., Vol. 176, pp. 585-593, Materials Research Society, Pittsburgh, PA (1988). 
${ }^{22}$ N. E. Bibler and J. K. Bates, "Product Consistency Leach Tests of Savannah River Site Radioactive Waste Glasses," Mat. Res. Soc. Symp. Proc., Vol. 176, pp. 327-338, Materials Research Society, Pittsburgh, PA (1990).

${ }^{23}$ C.W. Hsu and J.A. Ritter. "Treatment of Simulated High-Level Radioactive Waste with Formic Acid: Bench-Scale Study on Hydrogen”. Nuclear Technology 16, p 196 (1996).

${ }^{24}$ R.E. Eibling, "Formic Acid - Nitric Acid Compatibility in DWPF (U)". WSRC-RP-921247, Savannah River Site, Aiken, SC 29808 (1992).

${ }^{25}$ D. K. Peeler, T. B. Edwards, K. G. Brown, R. J. Workman, and I. A. Reamer, "Reduction of Constraints: Applicability of the Homogeneity Constraint for Macrobatch 3 (U)," WSRC-TR-200000358, February 15, 2001.

${ }^{26}$ C.M. Jantzen and K.G. Brown, "Impact of Phase Separation on Waste Glass Durability", Environmental Issues and Waste Management Technologies in the Ceramic and Nuclear Industries, V, G.T. Chandler, ed, Ceramic Transactions, V, pp. 289-300 (2000)

${ }^{27}$ M. A. Rios-Armstrong, "SME Acceptability for Macrobatch 3 Shielded Cells Run (U)," Interoffice Memorandum HLW-DEN-2001-00264, November 15, 2001.

${ }^{28}$ T.L. Fellinger, "Macro Batch 3 Demonstration in the Shielded Cells (U)," WSRC-NB-2000-00166.

${ }^{29}$ T.L. Fellinger, "Macro Batch 3 Demonstration in the Shielded Cells - Book 2 (U)," WSRC-NB2001-00162.

${ }^{30}$ T.L. Fellinger, "Macro Batch 3 Demonstration in the Shielded Cells - Book 3 (U)," WSRC-NB2001-00163. 
WSRC-TR-2002-00096

Westinghouse Savannah River Company

Revision 0

Savannah River Technology Center

APPENDIX A - INPUTS AND ASSUMPTIONS USED FOR CONVERTING FROM SRTC TO DWPF

SCALE

Table A-1. SRTC and DWPF Sludge Volumes and Purge Rates Used for SME Cycle and Redox Adjustment Cycle

\begin{tabular}{|l|c|c|c|c|}
\hline & $\begin{array}{c}\text { SME Cycle } \\
\text { SRTC Basis }\end{array}$ & $\begin{array}{c}\text { SME Cycle } \\
\text { DWPF Basis }\end{array}$ & $\begin{array}{c}\text { Redox Cycle SRTC } \\
\text { Basis }\end{array}$ & $\begin{array}{c}\text { Redox Cycle } \\
\text { DWPF Basis }\end{array}$ \\
\hline Sludge Volume & $0.722 \mathrm{~L}$ & $\begin{array}{c}22710 \mathrm{~L} \\
(6000 \mathrm{gal})\end{array}$ & $0.540 \mathrm{~L}$ & $\begin{array}{c}22710 \mathrm{~L} \\
(6000 \mathrm{gal})\end{array}$ \\
\hline Purge Rate $\left(\mathrm{F}_{\text {in }}\right)$ & $20.5 \mathrm{sccm}$ & $\begin{array}{c}1.869 \times 10^{6} \mathrm{sccm} \\
(66 \mathrm{scfm})\end{array}$ & $14.5 \mathrm{sccm}$ & $\begin{array}{c}1.869 \times 10^{6} \mathrm{sccm} \\
(66 \mathrm{scfm})\end{array}$ \\
\hline
\end{tabular}

Note that the purge rates above are those actually observed during the SME cycle and SME redox adjustment cycle. They are slightly different than the purge rates given in Appendix B (19.8 sccm for the SME cycle) and Appendix C (14.8 sccm for the redox adjustment cycle).

\section{Definition of Standard Conditions:}

Temperature $=21.1^{\circ} \mathrm{C}$ or $70^{\circ} \mathrm{F}$ (This is the temperature used by SRS flow calibration personnel)

Pressure $=1 \mathrm{~atm}$

Assumption: The gasses produced behave as ideal gasses, i.e. volume $\%=$ mole $\%$, and 1 mole $=2.41 \times 10^{4}$ cc (calculated using ideal gas law $\mathrm{PV}=\mathrm{nRT}$, with $\mathrm{P}=1 \mathrm{~atm}$ and $\mathrm{T}=21.1^{\circ} \mathrm{C}$ )

\section{Conversion of the SRTC Volume \% to DWPF Volume \%}

To convert from SRTC to DWPF scale volume \%, one must adjust for differences in sludge volumes and purge rates.

$$
\text { vol } \% D W P F=\text { vol\% SRTC } \cdot \frac{\text { DWPF Sludge Volume }}{\text { SRTC Sludge Volume }} \cdot \frac{\text { SRTC Purge Rate }}{\text { DWPF Purge Rate }}
$$

For the SME Cycle:

$$
\frac{22710 \mathrm{~L} \text { DWPF Sludge }}{0.722 \mathrm{~L} \mathrm{SRTC} \mathrm{Sludge}} \cdot \frac{20.5 \mathrm{sccm} \text { SRTC purge }}{1.869 \times 10^{6} \mathrm{sccm} \text { DWPF purge }}=0.345 \frac{\mathrm{vol} \% \text { DWPF }}{\text { vol\% SRTC }}
$$

For the Redox Adjustment Cycle:

$$
\frac{22710 \text { L DWPF Sludge }}{0.540 \text { L SRTC Sludge }} \cdot \frac{14.5 \text { sccm SRTC purge }}{1.869 \times 10^{6} \text { sccm DWPF purge }}=0.326 \frac{\mathrm{vol} \% \text { DWPF }}{\text { vol\% SRTC }}
$$

\section{Calculation of Gas Generation Rate}

The DWPF scale gas generation rate is calculated by

1. Calculating the flow out of the SRTC vessel

2. Calculating the gas generation rate in the SRTC vessel by multiplying the measured volume $\%$ by the flow rate out of the vessel

3. Converting the SRTC generation rate from $\mathrm{cc} / \mathrm{min}$ to $\mathrm{lb} / \mathrm{hour}$ 
4. Scaling the SRTC rate to DWPF basis

1. The flow rate out of the vessel is calculated by a helium balance.

$$
F_{\text {out }}=F_{\text {in }} \cdot \frac{c_{H e}}{x_{H e}}
$$

where $c_{H e}$ is the volume $\%$ helium in the purge gas, and Fin is flow into vessel (purge rate) and $x_{H e}$ is the measured volume $\%$ helium.

2. The SRTC gas generation rate is then:

$$
\text { SRTC Gas gen rate }=\frac{x_{i}}{100} \cdot F_{\text {out }}
$$

where $x_{i}$ is the measured vol $\%$ of gas $i$.

3. The SRTC gas generation rate (SGGR) is then converted from $\mathrm{cc} / \mathrm{min}$ to $\mathrm{lb} / \mathrm{hr}$ :

$$
\mathrm{SGGR} \mathrm{cc/min} \cdot \frac{\mathrm{mol}}{2.41 \mathrm{E} 4 \mathrm{cc}} \cdot \frac{M_{i} \mathrm{~g}}{\mathrm{~mol}} \cdot \frac{1 \mathrm{lb}}{454 \mathrm{~g}} \cdot \frac{60 \mathrm{~min}}{1 \text { hour }}
$$

where $M_{i}$ is the molecular weight of gas $i$.

4. To scale the gas generation rate from SRTC to DWPF, the ratio of sludge volumes is used:

$$
\text { Gen Rate Scale Factor }=\frac{\text { DWPF Sludge Volume }}{\text { SRTC Sludge Volume }}
$$

Combining the above:

DWPF Gas Gen Rate $=F_{\text {in }} \cdot \frac{x_{i}}{100} \cdot \frac{c_{H e}}{x_{H e}} \cdot \frac{\mathrm{mol}}{2.41 \mathrm{E} 4 \mathrm{cc}} \cdot \frac{M_{i} \mathrm{~g}}{\mathrm{~mol}} \cdot \frac{1 \mathrm{lb}}{454 \mathrm{~g}} \cdot \frac{60 \mathrm{~min}}{1 \text { hour }} \cdot \frac{\text { DWPF Sludge Vol }}{\text { SRTC Sludge Vol }}$

In the SME cycle, little gas was generated as evidenced by a variation of $+/-10 \%$ on the output helium concentration. Therefore, it was assumed that flow into the vessel was equal to flow out of the vessel, and $c_{\mathrm{He}}$ was equal to $x_{H e}$. Substituting known values, and combining terms, Equation A-7 becomes:

$$
\text { SME Cycle DWPF Gas Gen Rate }=x_{i} \cdot M_{i} \cdot 3.54 \times 10^{-2}
$$

For the SME Redox Cycle, $c_{H e}$ is equal to $0.48 \%$, as measured by the $\mathrm{GC}^{*}$. Inputting known values and combining terms, Equation A-7 reduces to:

$$
\text { SME Redox Cycle DWPF Gas Gen Rate }=x_{i} \cdot \frac{M_{i}}{x_{H e}} \cdot 1.605 \times 10^{-2}
$$

\footnotetext{
* The purge gas contains $0.46 \%$ helium. However, after purging the vessel, the GC recorded $0.48 \%$ helium. This difference is within the expected accuracy of the GC calibration, and the as measured value is used for calculations.
} 
Table A-2. SME Cycle Maximum Gas Concentrations and Generation Rates

\begin{tabular}{|c|c|c|c|}
\hline & $\mathbf{H}_{2}$ & $\mathrm{CO}_{2}$ & $\mathbf{N}_{2} \mathrm{O}$ \\
\hline Molecular Weight $\left(M_{i}\right)$ & 2.0 & 44.0 & 44.0 \\
\hline $\begin{array}{c}\text { SRTC Scale Maximum } \\
\text { Vol. } \%\left(x_{i}\right)\end{array}$ & 0.043 & 1.9 & 0.111 \\
\hline $\begin{array}{c}\text { DWPF Scale Maximum } \\
\text { Vol. \% (Eq. A-1) }\end{array}$ & 0.015 & 0.67 & 0.039 \\
\hline $\begin{array}{c}\text { DWPF Scale Generation } \\
\text { Rate (lb/hr) } \\
\text { (Eq. A-7a) }\end{array}$ & 0.0030 & 3.0 & 0.17 \\
\hline
\end{tabular}

Table A-3. SME Redox Adjustment Cycle Maximum Gas Concentrations and Generation Rates

\begin{tabular}{|c|c|c|c|}
\hline & $\mathbf{H}_{\mathbf{2}}$ & $\mathbf{C O}_{\mathbf{2}}$ & $\mathbf{N}_{\mathbf{2}} \mathbf{O}$ \\
\hline Molecular Weight $\left(\boldsymbol{M}_{\boldsymbol{i}}\right)$ & 2.0 & 44.0 & 44.0 \\
\hline $\begin{array}{c}\text { He Vol. \% at Maximum } \\
\text { Gas Concentrations }\left(\boldsymbol{x}_{\boldsymbol{H}}\right)\end{array}$ & 0.48 & 0.39 & 0.43 \\
\hline $\begin{array}{c}\text { SRTC Scale Maximum } \\
\left.\text { Vol. \% ( } \boldsymbol{x}_{\boldsymbol{i}}\right)\end{array}$ & 0.11 & 11.4 & 0.74 \\
\hline $\begin{array}{c}\text { DWPF Scale Maximum } \\
\text { Vol. \% (Eq. A-1) }\end{array}$ & 0.036 & 3.7 & 0.24 \\
\hline $\begin{array}{c}\text { SRTC Scale Vol\% at Max } \\
\text { Gas Generation Rate }\end{array}$ & 0.11 & 11.4 & 0.73 \\
\hline $\begin{array}{c}\text { He Vol\% at Max Gas } \\
\text { Generation Rate }\end{array}$ & 0.48 & 0.39 & 1.3 \\
\hline $\begin{array}{c}\text { DWPF Scale Generation } \\
\text { Rate (lb/hr) } \\
(\text { Eq. A-7b) }\end{array}$ & 0.0071 & 20.6 & \\
\hline
\end{tabular}


Westinghouse Savannah River Company

WSRC-TR-2002-00096

Savannah River Technology Center

Revision 0

\section{APPENDIX B - CALCULATIONS FOR THE SME CYCLE}

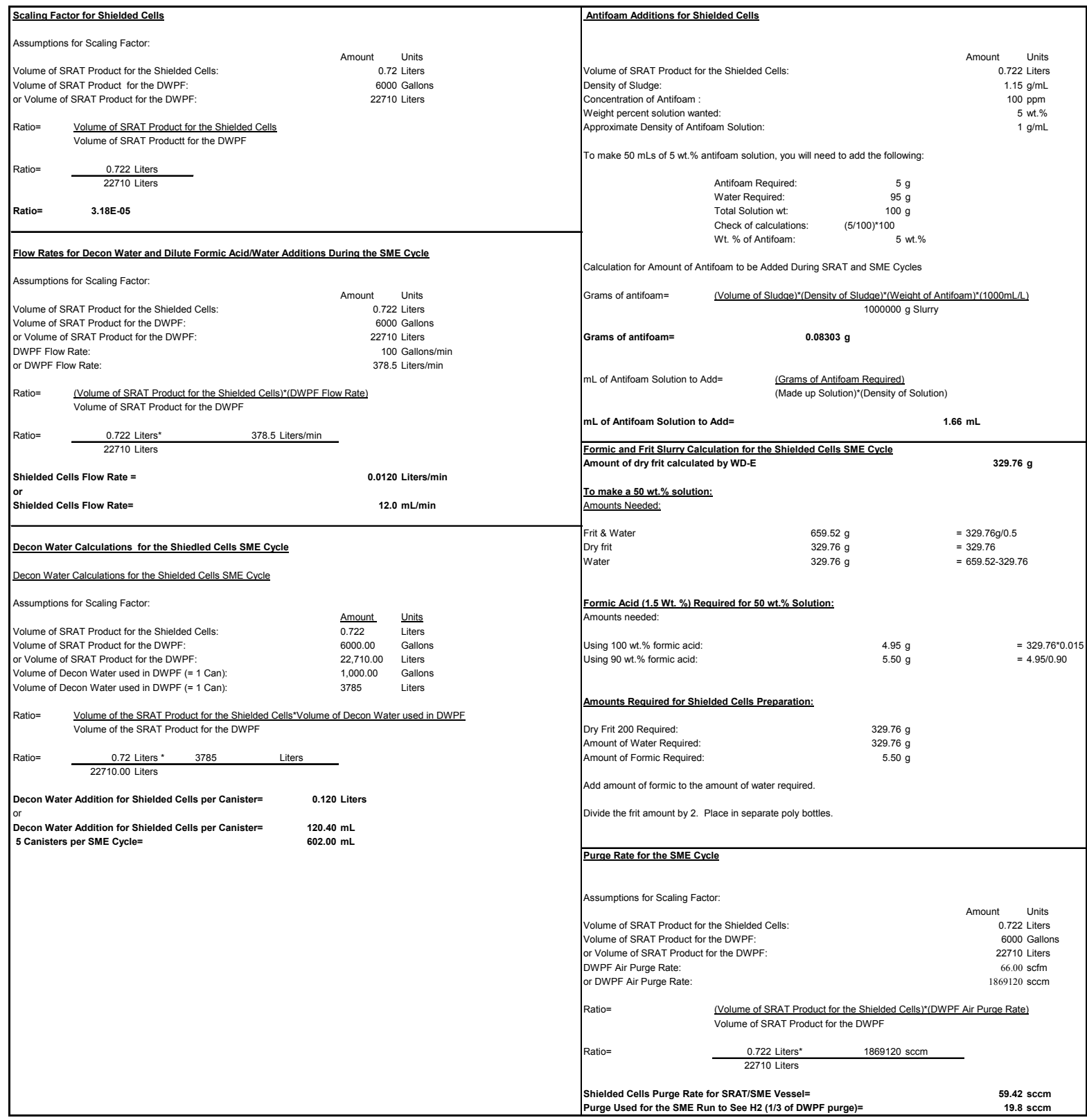


WSRC-TR-2002-00096

Westinghouse Savannah River Company

Revision 0

Savannah River Technology Center

\section{APPENDIX C - CALCULATIONS FOR THE SME REDOX CYCLE}

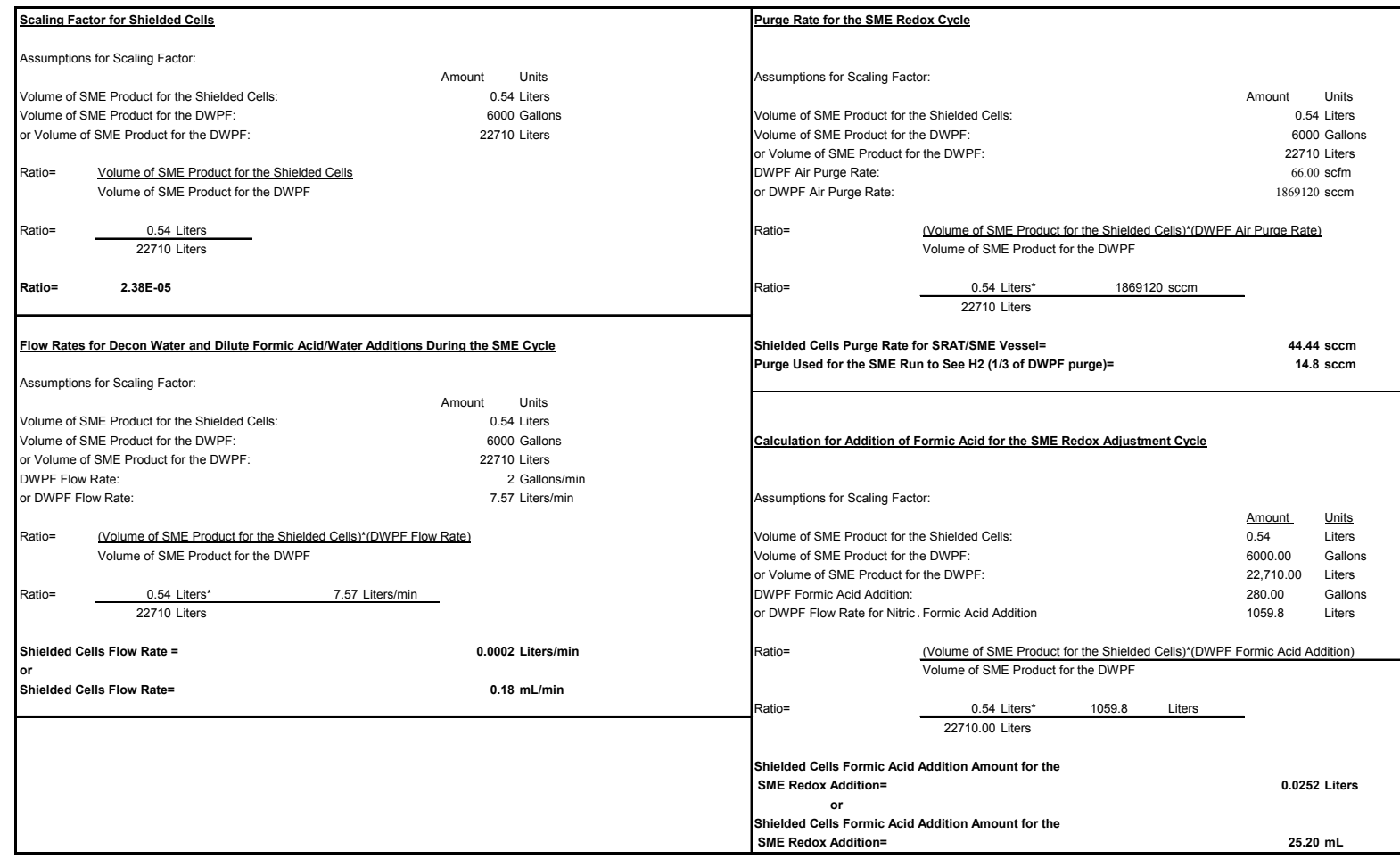




\section{APPENDIX D - CALCULATION OF THE WEIGHT PERCENT SOLUBLE AND INSOLUBLE SOLIDS AND VITRIFICATION FACTOR}

The soluble and insoluble weight percent solids can be calculated by using the following equations ${ }^{\dagger}$ once the weight percent total solids and dissolved solids have been obtained.

$$
\begin{gathered}
W_{i s}=\frac{\left(W_{t s}-W_{d s}\right)}{\left(1-W_{d s}\right)} \\
W_{s s}=W_{t s}-W_{i s}
\end{gathered}
$$

where $W_{d s}$ is the weight fraction of dissolved solids (weight of dissolved solids/weight of supernate)

$W_{t s}$ is the weight fraction of total solids (weight of total solids/weight of sludge slurry)

$W_{i s}$ is the weight fraction of insoluble solids (weight of insoluble solids/weight of sludge slurry)

$W_{s s}$ is the weight fraction of soluble solids (weight dissolved solids/weight of sludge slurry)

Converting the weight percent total and dissolved solids from Table 4 into weight fractions and inserting into Equations 1 and 2 yields:

$$
\begin{gathered}
W_{i s}=\frac{(0.453-0.0764)}{(1-0.0764)}=0.408 \\
W_{s s}=0.453-0.408=0.045
\end{gathered}
$$

Multiplying the above results by 100 to convert to percent yields:

$40.8 \mathrm{wt} \%$ insoluble solids

$4.5 \mathrm{wt} \%$ soluble solids.

The vitrification factor is defined as the grams of glass per $\mathrm{mL}$ of SME product. For this calculation, the weight percent calcined solids was used. A sample of SME product was calcined at $1000^{\circ} \mathrm{C}$. The resulting "calcine" was black and shiny, resembling glass. Therefore, the vitrification factor is calculated as follows:

$\mathrm{wt} \%$ calcined solids/100 $\mathrm{x}$ density of SME product, or

$\frac{41.6 \mathrm{~g} \text { calcined solids }}{100 \mathrm{~g} \mathrm{SME} \text { product }} \cdot \frac{1.36 \mathrm{~g} \mathrm{SME} \text { product }}{\mathrm{mL} \mathrm{SME} \mathrm{product}}=0.566 \mathrm{~g}$ glass $/ \mathrm{mL} \mathrm{SME} \mathrm{product}$

\footnotetext{
${ }^{\dagger}$ M.S. Hay and N.E. Bibler, "Characterization and Decant of the Tank 42 Sludge Sample ESP-200 (U)", WSRC-RP-98-00406, Rev. 0, June 12, 1998.
} 